\title{
Review
}

\section{The filter-press FM01-LC laboratory flow reactor and its applications}

\author{
Fernando F. Rivera ${ }^{\mathrm{a}}$, Carlos Ponce de León ${ }^{\mathrm{b}}$, José L. Nava ${ }^{\mathrm{a}}$, Frank C. Walsh ${ }^{\mathrm{b}, *}$ \\ a University of Guanajuato, Departamento de Ingeniería Geomática e Hidráulica, Av. Juárez 77, Zona Centro, C.P. 36000, Guanajuato, Mexico \\ ${ }^{\mathrm{b}}$ Electrochemical Engineering Laboratory, Energy Technology Research Group, Engineering Sciences, University of Southampton, Highfield, Southampton, SO17 \\ 1BJ, United Kingdom
}

\section{A R T I C L E I N F O}

\section{Article history:}

Received 13 October 2014

Received in revised form 16 December 2014

Accepted 20 February 2015

Available online xxx

\section{Keywords:}

electrolyser

energy storage

environmental remediation FM01-LC mass transport

metal ion removal

inorganic and organic electrosynthesis

water treatment

\begin{abstract}
A B S T R A C T
The FM01-LC is a laboratory-scale, electrochemical filter-press cell with a projected electrode area of $64 \mathrm{~cm}^{2}$ and a rectangular electrolyte flow channel which was originally based on the larger FM21-SP electrolyser of $2100 \mathrm{~cm}^{2}$ projected electrode area designed for the chlor-alkali industry then diversified to other applications. Many laboratories and industries have utilised this type of controlled flow reactor containing plane parallel electrodes in a rectangular channel for industrial and commercial applications. The diverse range of electrodes possible in such cells is emphasized with examples including 3-D metals and carbon, coated metal electrodes and nanostructured surfaces offering a high surface area. The experimental characterization and computational modelling of its reaction environment are concisely described discussed to appreciate the features of this type of electrochemical reactor. The cell construction and reaction environment are summarized, followed by an illustration of its use for a range of applications that include organic and inorganic electrosynthesis, metal ion removal, energy storage, environmental remediation (e.g., precious metal recycling or anodic destruction of organics) and drinking water treatment. Examples of the cell for energy conversion and storage (flow batteries and proton exchange membrane fuel cells) are briefly illustrated. The use of such a flow cell for the characterization of new electrochemical processes and to provide data enabling scale-up is considered.
\end{abstract}

(c) 2015 Elsevier Ltd. All rights reserved.

\section{Contents}

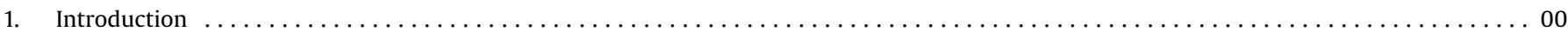

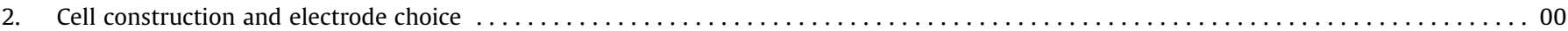

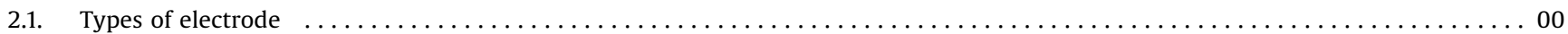

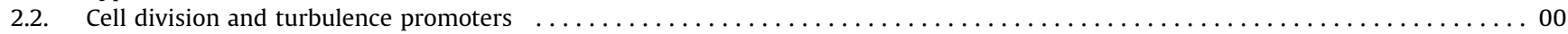

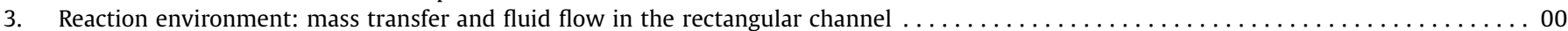

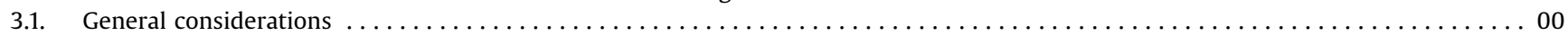

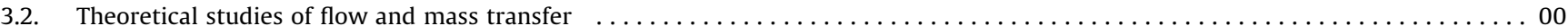

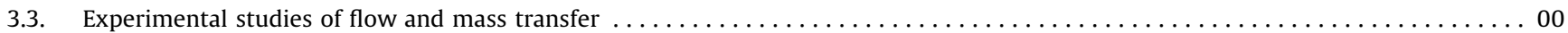

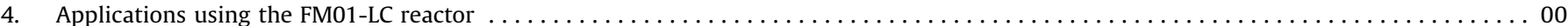

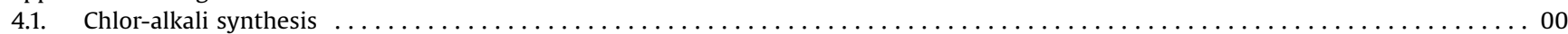

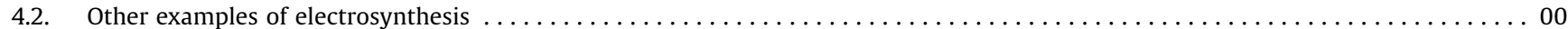

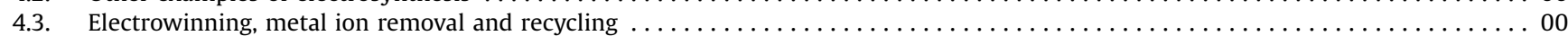

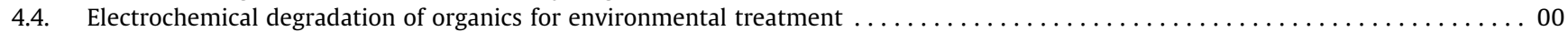

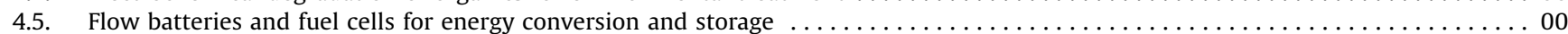

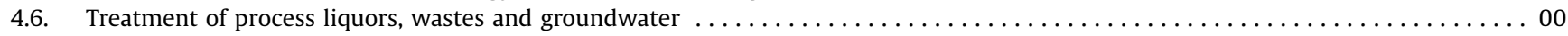

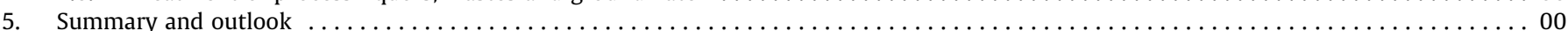

Abbreviations: BDD, boron doped diamond; BOD, biochemical oxygen demand; COD, chemical oxygen demand; DSA, dimensionally stable anode; FAD, formamidine disulphide; RVC, reticulated vitreous carbon.

* Corresponding author.

E-mail addresses: ffri@ugto.mx (F.F. Rivera), capla@soton.ac.uk (C.P. de León), jlnm@ugto.mx (J.L. Nava), f.c.walsh@soton.ac.uk (F.C. Walsh). 


\section{Nomenclature}

List of synmbols

A electrode area $\left(\mathrm{cm}^{2}\right)$

$A_{X S}$ cross sectional area of rectangular flow channel $\left(A_{X S}=B . S\right)\left(\mathrm{cm}^{2}\right)$

$B \quad$ breadth (width) of electrode $(\mathrm{cm})$

$c_{b} \quad$ bulk reactant concentration $\mathrm{mol}\left(\mathrm{cm}^{-3}\right)$

$c_{(0)}$ reactant concentration at time zero $\left(\mathrm{mol} \mathrm{cm}^{-3}\right)$

$c_{(t)} \quad$ reactant concentration at time $t\left(\mathrm{~mol} \mathrm{~cm}^{-3}\right)$

$d_{e} \quad$ equivalent diameter of flow channel, $d_{e}=2 B . S /(B+S)$ (cm)

$D \quad$ diffusion coefficient of electroactive species $\left(\mathrm{cm}^{2} \mathrm{~s}^{-1}\right)$

$E^{o c} \quad$ Open circuit electrode potential (V)

$E_{a}{ }^{o c} \quad$ Open circuit anode potential (V)

$E_{c}{ }^{o c} \quad$ Open circuit cathode potential $(\mathrm{V})$

$E_{\text {cell }}{ }^{o c}$ Open circuit cell potential (V)

F Faraday constant $\left(96,485 \mathrm{C} \mathrm{mol}^{-1}\right)\left(\mathrm{C} \mathrm{mol}^{-1}\right)$

I current (A)

$I_{L} \quad$ limiting current under convective-diffusion mass transport (A)

$j \quad$ current density $\left(\mathrm{Acm}^{-2}\right)$

$j_{L} \quad$ limiting current density under convective-diffusion mass transport $\left(\mathrm{A} \mathrm{cm}^{-2}\right)$

$k_{m} \quad$ mass transfer coefficient under convective-diffusion $\left(\mathrm{cm} \mathrm{s}^{-1}\right)$

$K \quad$ constant in Eq.id=6\#(3) (dimensionless)

$n \quad$ amount of material $(\mathrm{mol})$

$q \quad$ electrical charge (As)

Q volumetric flow rate of electrolyte $\left(\mathrm{cm}^{3} \mathrm{~s}^{-1}\right)$

$S$ electrode-wall or electrode-membrane separation (cm)

$t \quad$ time (s)

$t_{F} \quad$ total batch electrolysis time (s)

$v \quad$ mean linear electrolyte velocity in channel and past the electrode surface $\left(\mathrm{cm} \mathrm{s}^{-1}\right)$

$V \quad$ volume of electrolyte in the tank $\left(\mathrm{cm}^{3}\right)$

$w \quad$ velocity exponent in Eq.id $=6 \#(4)$ (dimensionless)

$x \quad$ distance along electrode from electrolyte inlet end (cm)

$X_{A} \quad$ fractional conversion of reactant (dimensionless)

$\mathrm{z}$ number of electrons involved in the reaction (dimensionless)

Dimensionless groups

$\theta$ Dimensionless time for a batch electrolysis $\left(\theta=t / t_{T}\right)$ (dimensionless)

Re Reynolds number $\left(R \mathrm{e}=v \cdot d_{e} / v\right)$ (dimensionless)

Sc Schmidt number $(S c=v / D)$ (dimensionless)

Sh Sherwood number $\left(S h=k_{m} \cdot d_{e} / D\right)$ (dimensionless)

Greek

$\varepsilon \quad$ volumetric porosity (dimensionless)

$v$ kinematic viscosity of electrolyte $\left(\mathrm{cm}^{2} \mathrm{~s}^{-1}\right)$

$\phi$ current efficiency (dimensionless)

$\lambda$ ratio of mass transport limiting current to total current (dimensionless)

$\tau_{T}$ residence time of electrolyte in the tank (s)

\section{Introduction}

The design of an electrochemical flow cell depends strongly on the intended application but important general factors in reactor performance [1] include: a) a uniform current density distribution, b) a uniform electrode potential distribution, c) high mass transport rates, d) the ability to handle solid, liquid, or gaseous products, e) the form of the product and the ease of product extraction, f) simplicity of design, installation, and maintenance, $g$ ) availability of electrode and membrane materials, h) capital and running costs and i) integration with other process needs.

These needs are well met by controlled flow, plane parallel cells, often in a modular, expandable, filter-press design [2]. Preliminary studies of electrode materials and operational conditions often take place in simple batch vessels, such as a beaker or tank equipped with parallel plate electrodes and a magnetic stirrer to provide electrolyte agitation. While such a system is simple and convenient in the laboratory, it is not always appreciated that the cell involves a complex and poorly-defined flow environment which is difficult to reproduce and scale. In order to provide quantitative information on the effects of flow and mass transport to facilitate scale-up, it is necessary to use a controlled flow cell, plane parallel electrodes in a rectangular channel providing a welldefined but flexible cell design, which may accommodate:

1. textured (e.g., slotted, perforated, louvred or expanded mesh electrodes to facilitate gas evolution, as seen in the examples of Fig. 1),

2. coated electrodes to offer robust, catalytic surfaces,

3. profiled or porous, 3-D electrode structures to achieve a high active electrode area and moderate rates of mass transport, examples being given in Fig. 1),

4. polymer mesh turbulence promoters to improve electrolyte flow, current distribution and mass transport rates or

5. microporous separators or ion-exchange membranes for cell division.

A number of commercially available flow cells using rectangular flow channels, for laboratory use were introduced in the 1980s, such as the ElectroCell, Dished electrode membrane, DEM cell and FM01-LC electrolyser [3] and have been extensively used, together with home-made cells for electrosynthesis and environmental processing [4]. The authors have chosen the FM01-LC to illustrate the applications possible in a laboratory filter-press flow cell deploying a plane parallel electrode geometry in a rectangular flow channel since this cell has often been used in their laboratories for computational cell design programmes and to characterize diverse reactions involving electrosynthesis, environmental control or energy conversion. It is important to realise that many of the general characteristics of the cell and applications described are relevant to other well-designed controlled flow laboratory cells offering rectangular flow channels.

As in the case of the FM21-SP electrolyser (ICI-Chemicals and Polymers Ltd now INEOS Chlor-Chemicals) of $2100 \mathrm{~cm}^{2}$ geometrical electrode area [5], the smaller FM01-LC laboratory-scale electrochemical cell (projected area of $64 \mathrm{~cm}^{2}$ ) is constructed in a parallel plate-and-frame filter press configuration. The larger (FM21-SP) cell was specifically designed for the chlor-alkali industry [5] while the FM01-LC was designed as a versatile laboratory cell for preliminary trials of different electrode processes and comprises electrodes, spacers, ion-exchange 


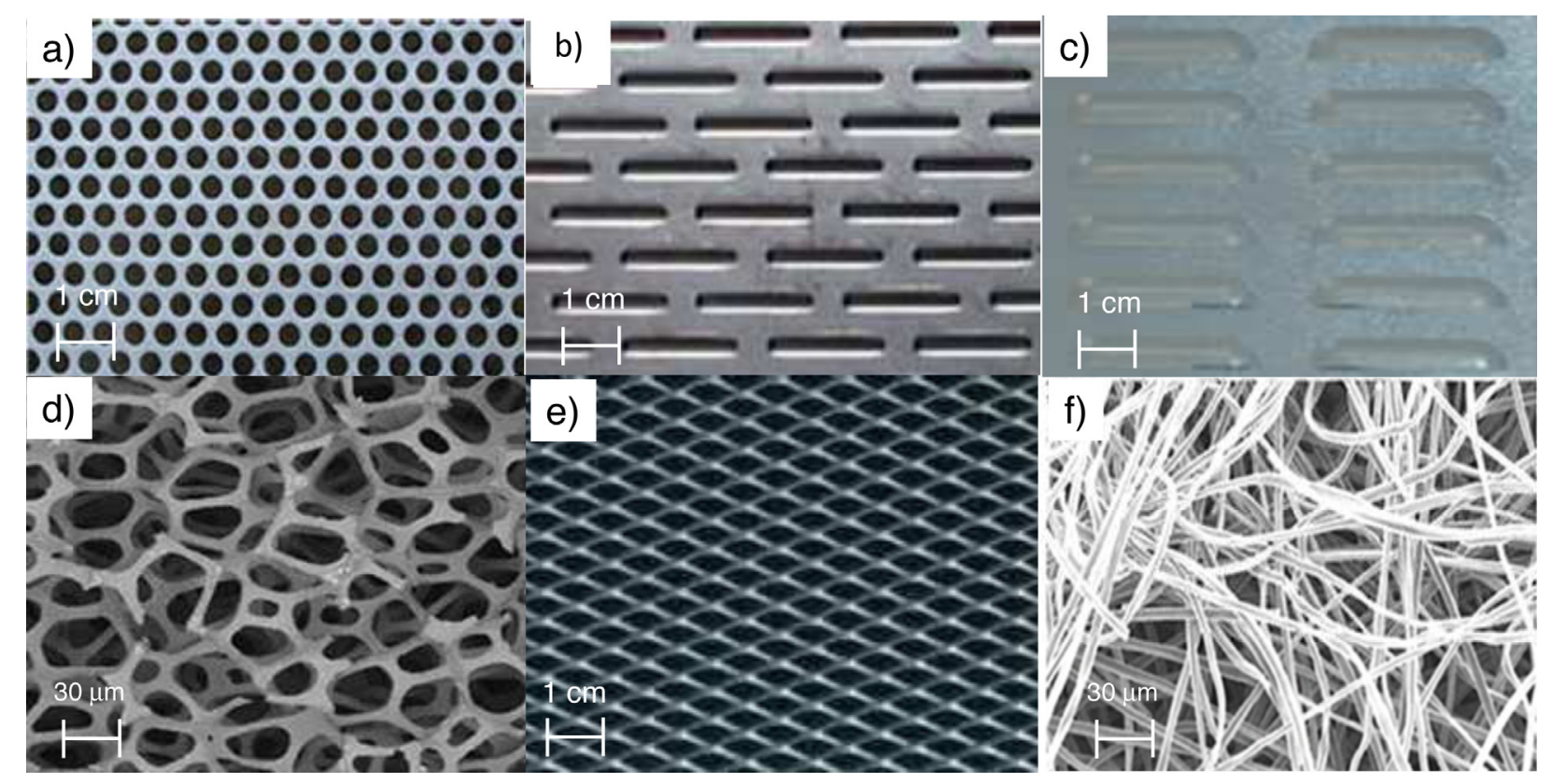

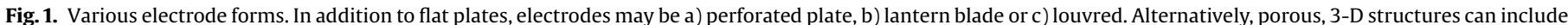
d) porous mesh, e) expanded mesh, or f) carbon felt as well as carbon or metal foams.

membranes and gaskets compressed between two electrically insulated end plates as shown in Fig. 2. The design rationale included facile manufacture of spacers and electrodes, avoidance of multiple discrete ' $O$ ' ring seals, and the ability to incorporate different electrodes, separators (or ion exchange membranes) and turbulence electrodes in a chemically resistant package suitable for a wide range of electrolyte compositions and a wide temperature range.

The available electrode area in the FM01-LC reactor can be readily increased by building up a series of standard size electrode plates, or by the use of additional stacks. The reactor is well suited to laboratory feasibility studies in application areas such as electrosynthesis, environmental treatment and redox flow cells, together with investigations of the effect of process variables on electrochemical reactions and the reaction environment. The cell components originally supplied by ICI C \& P included $3.9 \mathrm{~mm}$ thick white PTFE spacers and $1.5 \mathrm{~mm}$ thick, blue, glass-filled PTFE gaskets. The use of standard, $5 \mathrm{~mm}$ thick flow channels and $0.5 \mathrm{~mm}$ flat, compressed sealing gaskets typically results in an inter-electrode or electrode-membrane gap of 5.5 to $6.0 \mathrm{~mm}$. The flow compartment is usually machined from a $0.55 \mathrm{~cm}$ thick polymer sheet. The rectangular flow aperture in this channel usually has a width of $4.0 \mathrm{~cm}$ and a length of $16.0 \mathrm{~cm}$, defining an equivalent (hydraulic) diameter $\left(d_{e}=2 B S /(B+S)\right.$ of ca. $1 \mathrm{~cm}$ and a nominal flow channel volume of ca. $35 . \mathrm{cm}^{3}$. This rectangular flow channel is fed by four distributor channels which take the external electrolyte through a circular tube of area $0.5 \mathrm{~cm}^{3}$. Diverse electrolyte flow rates have been used in the range 2.2 to $44 \mathrm{~cm}^{3} \mathrm{~s}^{-1}$ corresponding to mean linear flow velocities of 1 to $20 \mathrm{~cm} \mathrm{~s}^{-1}$ past a planar electrode surface (although more extreme flow velocities have been used). Polymer mesh turbulence promoters of up to $5.5 \mathrm{~mm}$ thickness may be incorporated into the flow channel between the electrode surface and the other electrode (undivided cell) or membrane (divided cell). Unpublished work by the authors suggests that vertical operation of the cell, with the flow inlet at the bottom, provides an improved electrolyte flow dispersion and residence time distribution in comparison to a horizontal cell. One end plate of the cell can be conveniently secured to a mounting bracket allowing cell opening via loosening of the other end plate.

Experimental characterization of the filter-press FM01-LC reactor and modelling of its reaction environment will be considered in detail in a complementary review [7]. Following a description of electrodes and cells, the importance of reaction environment is considered. A general review of the versatility and uses of the filter-press-type FM01-LC electrolyser in applications including electrosynthesis [8,9], metal ion removal [10,11], electrochemical degradation of organic contaminants [12,12] and energy storage [14-16] is then presented.

\section{Cell construction and electrode choice}

The choice of cell components is wide to accommodate diverse reactions, electrolytes and process conditions but the need for versatility restricts the choice of cell body material (normally an easily machined polymer). In extreme cases, such as electrosynthesis of dinitrogen pentoxide in anhydrous nitric acid [17-21] in section 5.2, expensive fluorocarbon polymers might be used for the cell body and the electrolyte flow reservoir and tubing is normally fluorocarbon polymer based.

\subsection{Types of electrode}

There is diverse choice of electrode material, form and surface morphology since all three aspects control the active electrode area, electrocatalytic ability and mass transport characteristics. Decisions on the choice of electrode include several critical aspects:

a electrical connections, i.e., monopolar, where each electrode is electrically connected to the positive or negative of a power supply or bipolar, in which the end electrodes are connected to the power supply terminals leaving intermediate electrodes to become anodic on one side and cathodic on the other [4].

b anuncoated surface or one coated by a selected electrocatalyst or high surface area material. Choices have been greatly expanded by the increasingly wide range of vapour deposition techniques, 


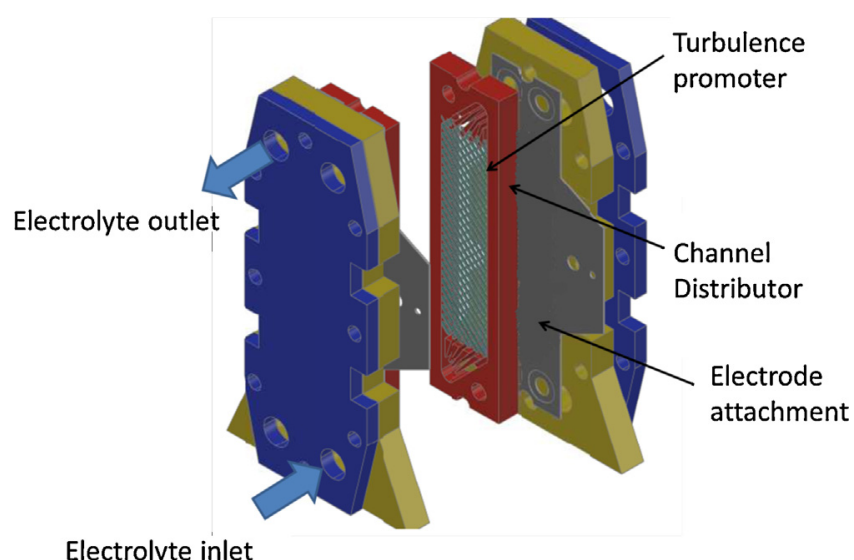

Electrolyte inlet

Fig. 2. The FM01-LC electrochemical reactor.

e.g., boron doped diamond by plasma vapour deposition and electrochemical techniques for depositing nanostructured solids, including nanocomposites by combining electrophoretic methods with electroplating ones [22].

c two- or three-dimensional material, e.g., a metal foil, a carbon plate or a porous 3-D material, such as reticulated vitreous carbon, RVC, nickel foam or carbon felt.

$\mathrm{d}$ the nature of the material, e.g., metal or ceramic e.g., carbon or conductive titanium oxide base

e monolithic or particulate, i.e., a one-piece structure or a constrained bed of multiple carbon or metal particles.

In the case of electrode structure, a smooth, planar surface recessed into the flow channel will always provide a simple condition from the viewpoints of fluid flow past it and its surface area being close to the geometrical value. Surface morphology may be altered by mechanical treatments, e.g., abrasion, grinding, polishing, by chemical etching or by application of a coating, e.g., by electrodeposition. The deposit may be nanostructured and increase the active surface area [23] or sufficiently rough to increase the rate of mass transport to the surface. For example, platinising might increase active surface area by up to 10 times while nanostructured nickel plating can realise surface areas $<50$ greater than a polished plate. For a fixed current density, $j$ the current flowing, hence the reactor duty is effectively given by the current for the desired reaction so the active area should be as high as possible as long as potential- and current distribution, pressure drop and economics are not compromised.

The form of the electrode can govern fluid flow since it can affect pressure drop, flow regime, mass transport via turbulence promotion [24] and provide a porous matrix for through flow of electrolyte, in the case of porous, 3-D electrodes. Such structures can be achieved by one-piece (monolithic) materials such as metal meshes, felts, textiles and foams or by particulate assemblies such as carbon or metal spheroids, fibres and tubes [25-27].

For example, nickel is readily available as thin, open cell foam, felt, sintered cloth, fibrous mat, expanded mesh, flat plate, foil or perforated mesh. Porous nickel has been used in our laboratories as a convenient substrate for mixed metal oxide electrocatalysts in alkaline metal-air flow batteries, e.g., as a bifunctional electrode in Zn-air batteries [28] and oxygen evolution in water electrolysers [29].

An attractive strategy is to use both form and surface morphology to improve performance. An example is the deposition of a high surface area metal deposit on a porous, flow distributing electrode scaffold, e.g., Au on RVC for fuel cells [30] or Pt on carbon felt for redox flow batteries [31].

\subsection{Cell division and turbulence promoters}

Division of the anode and cathode compartments complicates cell design and assembly but may confer important benefits, including:

a the separation of very different anolyte and catholyte solutions, e.g, an acid and an alkali,

b some independence of the anode and cathode chemistry or

c protection of the anode from aggressive species such as chloride ions.

The major decision necessary is the type of ionically conducting cell divider. An ion exchange membrane can offer a degree of ion selectivity, as in the case of a proton membrane together with a relatively thin $(50-200 \mu \mathrm{m})$ and conductive material. The mechanical strength of such membranes can be improved by the use of an integral polymeric reinforcing cloth. However, ion exchange membranes are relatively expensive. A much lower cost material is the microporous ceramic diaphragm or polymeric separator; the latter is typically $50-200 \mu \mathrm{m}$ thick) has no ionic structure and typical pore sizes of $10-50 \mu \mathrm{m}$ ).

It is well known that use of an empty channel in the electrolyser exaggerates the effect of inlet flow distributor, where jet flows predominate $[32,33]$. In practice, a plastic mesh can be used as turbulence promoter to homogenize flow pattern and improve mass transport in filter-press type reactors with parallel plate electrodes; experimental studies of mass transport showing the influence of different plastic mesh arrangements has been reported [34].

\section{Reaction environment: mass transfer and fluid flow in the rectangular channel}

\subsection{General considerations}

The control of reaction environment in a flow cell is extremely important because it can exert a major influence on reactor performance and operating costs, including the rate of an electrode reaction, current efficiency, selectivity of an electrosynthesis product and energy efficiency of a battery together with electrolysis and pumping costs. Aspects include the interrelated ones of global, local and, time-dependent:

a reaction kinetics, hence the electrode reaction rate, selectivity, active electrode area and electrocatalysis,

b electrolyte hydrodynamics in the flow channel and past the electrode surface, hence electrode geometry and roughness, flow regime, pressure drop across the cell and flow dispersion,

c mass transport of reactants to, and products away from, the electrode surface as a function of flow velocity, electrode type and nature of inert turbulence promoter.

d distribution of concentration, potential and current density across and along the electrode surface.

Reaction environment in the FM01-LC cell is extensively considered in a complementary review which is illustrated with examples of FM01-LC cell geometry and operation [7].

Here, the importance of fluid flow and mass transport is highlighted due to its importance in many applications.

At a fixed reactant concentration, the overall rate of an electrode process, as expressed by the overall rate of transformation of the reactant amount with time, $d n / d t$ can be related to the current, $I$, (with a current efficiency $\phi$ ) and is directly proportional to active electrode area, $A$ and can be expressed by Faraday's laws of 
electrolysis:

$\phi \cdot I=j \cdot A=\frac{d n}{d t} \cdot z \cdot F$

At a sufficiently high current, i.e. the limiting current, $I_{L}$, the reaction rate becomes mass transfer controlled and is restricted by convective-diffusion of the electroactive species from the bulk electrolyte to the electrode surface:

$I_{L}=k_{m} A \cdot z \cdot F \cdot c_{b}$

In order to increase the reaction rate, the mass transport rate must be enhanced by increasing the flow velocity, $v$ of electrolyte past the electrode surface, according to the general expression:

$I_{L}=K \cdot v^{w}$

where the constant, $K$ depends on electrode geometry, electrolyte composition and temperature and the mean linear electrolyte flow velocity, $v$ is:

$v=Q /(1-\varepsilon) B \cdot S$

$Q$ is the volumetric flow rate through a rectangular channel of breadth $B$ and separation $S$, hence flow cross sectional area of $B S$ while the volumetric porosity or voidage, i.e. the ratio of free space to solid material of a uniform porous material (promoter or electrode) in the flow channel, is $\varepsilon$. The velocity exponent, $x$ depends on the electrode geometry and flow regime [2]. It is useful comparison to illustrate average mass transfer rates as a function of flow velocity for several types of metal electrode. The data in Fig. 3 considers mass transfer rates to various electrodes in a rectangular

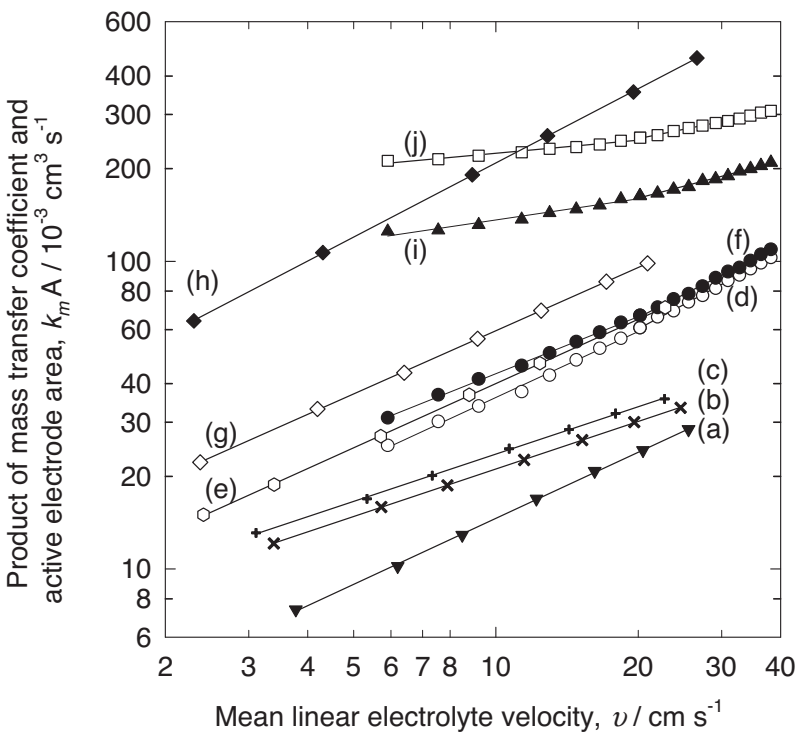

Fig. 3. Log-log plot of the product of mass transfer coefficient and active electrode area, $k_{\mathrm{m}} A v s$. mean linear flow velocity of electrolyte at 295-302 K: (a) Flat carbon plate [6], (b) 30 ppi RVC [6], (c) 60 ppi RVC [6], (d) solid mirror polished flat nickel plate in an empty channel [22], (e) nickel mesh twin grid (TWB) [36] (f) mirror polished flat plate nickel in the presence of a turbulence promoter in the flow channel [23], (g) 60 ppi RVC, (h) nickel stacked net [36], (i) nanostructured nickel deposit in the absence of a turbulence promoter [23] and (j) nanostructured nickel deposit in the presence of a turbulence promoter [23]. The limiting currents at nickel were obtained for reduction of ferricyanide ions from $0.001 \mathrm{~mol} \mathrm{dm}^{-3} \mathrm{~K}_{3} \mathrm{Fe}$ $(\mathrm{CN})_{6}$, in $1 \mathrm{~mol} \mathrm{dm}^{-3} \mathrm{~K}_{2} \mathrm{CO}_{3}$ at $29^{\circ} \mathrm{C}$ [23] or $1 \mathrm{~mol} \mathrm{dm}^{-3} \mathrm{KOH}$ [36], whereas those at carbon are for oxidation of hydroquinone from $0.01 \mathrm{~mol} \mathrm{dm}^{-3}$ hydroquinone in $0.5 \mathrm{~mol} \mathrm{dm}^{-3} \mathrm{pH} 7$ phosphate buffer at $25^{\circ} \mathrm{C}[36]$. flow channel in the temperature range $295 \mathrm{~K}$ to $302 \mathrm{~K}$ by recording the convective-diffusion limiting current for reduction of ferricyanide ions at nickel, typically in alkaline potassium hydroxide/ aqueous potassium carbonate:

$\mathrm{Fe}(\mathrm{CN})_{6}^{3-}+e^{-}=\mathrm{Fe}(\mathrm{CN})_{6}^{4-}$

or oxidation of hydroquinone (HQ) to quinone (Q) at carbon in $\mathrm{pH} 7$ phosphate buffer:

$H Q-2 e^{-}=Q+2 H^{+}$

Reactions (5) and (6) are well established choices for model mass transport measurements at inert electrode materials [35].

Assuming all of the electrode surface to be active for a reaction under complete mass transfer control due to convective-diffusion, the product of mass transfer coefficient and surface area in a an electrolyte at constant temperature is directly related to the bulk reactant concentration and limiting current density by:

$k_{m} \cdot A=j_{L} \cdot z \cdot F \cdot c_{b}$

For a mean linear flow velocity of electrolyte $<40 \mathrm{~cm} \mathrm{~s}^{-1}$, at a temperature of $25^{\circ} \mathrm{C}$. The following cases are considered in Fig. 3 :

1. a flat plate in an empty channel [36],

2. a flat plate with a polymer mesh turbulence promoter incorporated in the flow channel [23],

3. an expanded metal mesh in an empty channel [36,37],

4. a nickel wire mesh [36,37],

5. three porosity grades of carbon foam (RVC) in an empty channel [6],

6. a nickel foam in an empty channel [36,37],

7. a nanostructured deposit on a flat surface in an empty channel [23], and

8. a nanostructured deposit on a flat surface with a turbulence promoter in the channel [23].

It is clear that the product of transfer rate and surface area, hence the limiting current may be enhanced by:

a) a turbulence promoting polymer mesh in the flow channel,

b) a porous, 3-D metal or carbon electrode structure, or

c) a roughened electrode surface, a nanostructured deposit offering a high active surface area.

This behaviour may be compared with other rectangular flow channel cells using dimensionless group correlations. Mass transport to electrodes in channel flow can be expressed by the Sherwood number, $S h$. This is related to the fluid flow, expressed by the Reynolds number, $R e$ and the transport properties of the electrolyte represented by the Schmidt number, Sc. Typically, an aqueous electrolyte at $25^{\circ} \mathrm{C}$ has a kinematic viscosity of ca. $1 \times 10^{-2} \mathrm{~cm}^{2} \mathrm{~s}^{-1}$ and the electroactive species has a diffusion coefficient of $5 \times 10^{-6} \mathrm{~cm}^{2} \mathrm{~s}^{-1}$, giving a Sc value of 2000 . The fluid velocity range 1 to $40 \mathrm{~cm} \mathrm{~s}^{-1}$ corresponds to a Re number range of 100 to 4000 for a rectangular flow channel having an equivalent diameter of $1 \mathrm{~cm}$. The correlation for a rectangular channel may be expressed in the form:

$S h=a R e^{b} S c^{c}$

where $R \mathrm{e}=v d_{e} / v, S c=v / D$ and $\left.S h=k_{m} d_{e} / D\right)$. The values of $a, b$ and $c$ depend on electrode geometry, electrolyte composition, flow conditions and channel geometry; they are best found by regression of empirical mass transfer data. Typically, the Schmidt exponent is assumed to be one third, leaving the coefficients $a$ and 
$b$ to be found by linear regression of $S h$ and Re values in a log-log plot. In such dimensionless correlations, it is important to use an appropriate characteristic length in the Re and Sh numbers. We have preferred the simplicity and convenience of the equivalent diameter in channel-based Re and Sh numbers as it can be used to characterise flow velocity in the channel and mass transfer to the electrode surface within the channel, for a wide range of electrode materials. A wide range of electrolyte velocity has been used in the widespread literature although specific studies are often restricted to a much narrower range. For example, early studies tended to use values in the range 2 to $10 \mathrm{~cm} \mathrm{~s}^{-1}$ e.g. [38] while later work, e.g., [39] extended the maximum velocity to over $22 \mathrm{~cm} \mathrm{~s}^{-1}$. While higher electrolyte velocity enables higher mass transport rates, it inevitably incurs high pressure drops, especially through low porosity 3-D electrode materials [40].

\subsection{Theoretical studies of flow and mass transfer}

An important strategy to obtain the local behaviour within FM01-LC reactor is to solve the fundamental equations that describe the local velocity distributions at the bulk of FM01-LC and then to couple the results with mass conservation equations for describing local mass transport in reaction area. Computational fluid dynamics, CFD allows an improved evaluation of fluid flow within the FM01-LC reactor by considering the effect of local flow variations in order to improve predictions of performance during the scale-up of filter-press cells.

In recent years, developments in computational software have enabled many studies of FM01-LC modelling and simulation to describe fluid flow [41,42], mass transport characterization [43-45] current distribution and potential distribution [45]. From these studies, it is important to note that despite of the recent development of CFD techniques, these ones only are useful for describe the flow fluid in empty channels because the high computational resources that are required for the performance of other configurations like, foam electrodes, channel with turbulence promoters, and partitioned membrane cell that are important for many electrochemical applications. The experimental flow characterization allows to know the flow pattern in mentioned to establish operational conditions for electrochemical processes.

It is important to appreciate the compromise in using a high electrolyte flow velocity. Use of high flow velocities can realise high rates of mass transport but at the expense of high pressure drop (hence a greater risk of electrolyte leakage, higher pumping costs and, possibly, a larger, more expensive pump) together with a lower fractional conversion of reactant.

\subsection{Experimental studies of flow and mass transfer}

It is important to utilise computational modelling and experimental measurements in a balanced fashion to adequately characterise an electrochemical flow cell. Experimental measurements can include:

a limiting current, hence mass transfer coefficient for a model reaction under convective-diffusion control as a function of linear flow velocity of electrolyte past the electrode surface [34,39].

b pressure drop across the flow channel as a function of linear flow velocity of electrolyte past the electrode surface [40].

c voltammetry under controlled reactor conditions to confirm reaction kinetics at a given type of electrode under controlled flow conditions [46].

d reaction efficiency under controlled electrolysis conditions of a fixed batch of electrolyte to determine figures of merit such as current efficiency, selectivity and energy efficiency [6]. e charge-discharge performance of a secondary flow battery, including voltage-, charge- and energy efficiency [15].

Computational fluid dynamics techniques, using suitable software, prove useful to compute mass transport coefficients inside empty channels but the simulation of mass transport in the presence of turbulent promoters and 3-D electrodes requires experimental mass transport characterization for validation. Indeed, experimental characterization is the most important tool to evaluate the performance of electrochemical reactor with those different configurations. Because the complexity of obtain local flow variations and mass transport coefficients, by means of CFD in complex configurations, it is necessary to establish experimental correlations that can describe global predictions about particular configurations in filter-press FM01-LC reactor. Several studies on experimental characterization have been published and these can be divided into non-ideal flow [32,47,48], mass transport characterization $[34,38,40]$ and the effect of potential distribution on the limiting current density [49].

\section{Applications using the FM01-LC reactor}

\subsection{Chlor-alkali synthesis}

INEOS Chlor-Chemical (ICI) in Runcorn, England has developed a different approach to zero-gap membrane cell technology where the tailored gaskets, fitted around each electrode, define the flow channels near the electrodes and partly fulfil the role of the cell body. One of these designs is the FM21-SP series, which formed the basis for the scale-down to the FM01-LC. These cells are operated with monopolar connections and are short but wide in order to minimize ohmic drops within the electrode structures.

A complete filter-press stack of membrane cells will contain typically $50-100$ cells and will be capable of producing $1 \times 10^{7} \mathrm{~kg}$ per year with cell rooms using the FM21-SP configuration. It can also see that it is straightforward to vary the number of cells in each electrolyser unit and hence, to build plants with various capacities. The cell voltage can be as low as $2.7 \mathrm{~V}$ in membrane cells with ruthenium oxide coated cathodes and anodes [4,37]. An example of chlorine production in an FM21-SP cell room is shown in Fig. 4. This installation at Ineos ChlorVinyls, Runcorn, UK has a production rate of 10 to 30 tonne day $^{-1}$ with an energy consumption of $2200 \mathrm{~W}$ h tonne $\mathrm{e}^{-1}$ [37].

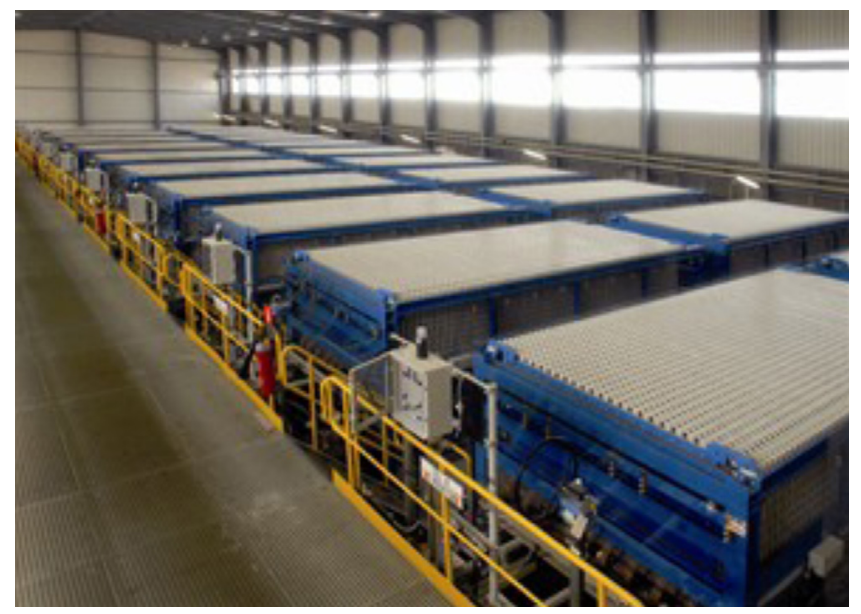

Fig. 4. A typical FM21-SP chlorine production cell room at Ineos ChlorVinyls, Runcorn, UK. The production rate is 10 to 30 ton day $^{-1}$ with an energy consumption of $2200 \mathrm{Wh} \mathrm{ton}^{-1}$. Further details are available in reference [37]. 
Table 1

Selected examples of electrosynthesis in the FM01-LC cell.

\begin{tabular}{|c|c|c|}
\hline Product & Electrodes used & Ref. \\
\hline Coumestan and catecholamine derivatives & RVC and other carbon anodes & {$[6]$} \\
\hline D,L-homocysteine-thiolactone hydrochloride & Carbon felt cathode & {$[8]$} \\
\hline Vanillin & Nickel anodes & [53] \\
\hline Dinitrogen pentoxide synthesis & Platinised niobium anodes & {$[17-21,55]$} \\
\hline FADS production from thiourea & Pt coated anodes & [57] \\
\hline
\end{tabular}

Despite the use of FM21-SP reactors in chlor-alkali industry, fundamental studies in FM01-LC to improve efficiency of this process have rarely been published. For example, Chikhi et al. [50] studied the secondary potential distribution in a FM01-LC membrane divided cell, through a 1-D potential distribution model (derived from the Laplace equation considered in a complementary review in this journal [7]). The distribution takes into account the effective conductivity of gas-liquid mixture. This was achieved by solution of the modified Laplace equation using commercial finite element method software; experimental current density measurements were determined using the segmented electrode method. The distribution takes into account the effective conductivity of gas-liquid mixture versus the gas volume fraction and the authors suggest an empirical equation valid up to $74 \%$ gas fraction assuming $100 \%$ efficiency for gas production and a phase velocity ratio of 1 [51].

Numerical simulation was compared with experimental results at anode and cathode, both flow by and flow through configurations being considered. The model is in accordance with the experimental results, except for the last segments. At this position, the experimental current density is higher than that found by calculations. The configuration of flow in the cell, with respect to the direction of current flow, influences the distribution of current density. As expected, the distribution is more uniform in the 'flow-by' than in the 'flow-through' configuration, the former involving a flow direction perpendicular to the direction of current flow [2,4]. Sufficient electrolyte flow can help to eliminate non- uniformities caused by the gas-filled

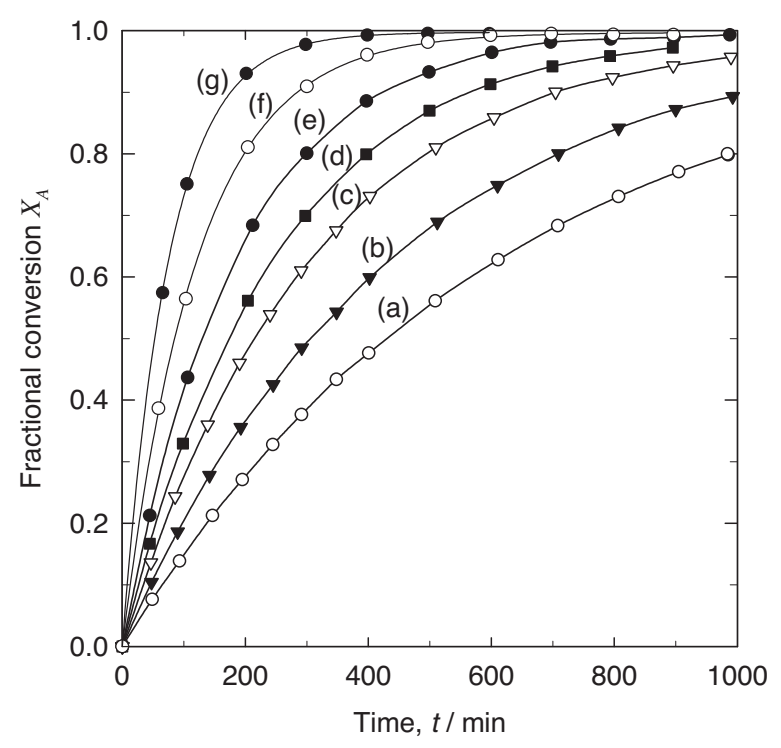

Fig. 5. Conversion of cathecolamine at different flow rates a) 2, b) 5, c) 10, d) 15, e) 20 , f) 25 and g) $30 \mathrm{~cm} \mathrm{~s}^{-1}$ in FM01-LC electrochemical reactor using an RVC electrode. After Szánto, Trinidad and Walsh [6]. electrolytes. These findings are useful to improve the overall efficiency during chlor-alkali electrolysis.

\subsection{Other examples of electrosynthesis}

Organic electrosynthesis can compete with conventional manufacturing technologies when the economics of the process are mainly affected by the cost of separation procedures, rather than by the energy consumption. The former is particularly relevant when a high purity product must be obtained, as usually occurs in the pharmaceutical industry. Due to the uniformity of potential and flow distributions, the FM01-LC electrochemical reactor has been deployed to study several organic synthesis processes, involving high purity products [52], as illustrated in Table 1.

A wide range of electrodes and conditions under which the FM01-LC reactor has been used in a laboratory environment and the performance of various carbon electrodes was described by Szantó et al. [6]. Reticulated vitreous carbon (RVC) has been used to provide a stable, inert, three-dimensional electrode surface for organic electrosynthesis; its performance was comparable to that of nickel mesh for the oxidation of catechol to o-quinone. This product was then reacted in-situ with (i) 4-hydroxycoumarin and (ii) 1,3 dimethyl barbituric acid to produce, respectively, coumestan and catecholamine, products of pharmaceutical interest. In mass transport experiments using hydroquinone oxidation as a model reaction, the performance was similar to that of nickel electrodes but Sherwood numbers were reduced by $<10 \%$ when carbon electrodes were used. The best-performing electrode made from RVC, however, showed poorer behaviour than its nickel counterpart. Yields for the production of coumestan and catecholamine were approximately $45 \%$ and $25 \%$, respectively, despite the high conversion of cathecol at different flow rates (Fig. 5). The product extraction problems were reflected in low current efficiencies in the region of $65-70 \%$. The electrode material, rather than the fluid flow behaviour, resulted in a reduction in overall cell efficiency; this was confirmed by studies which showed film formation on the electrode surface.

Galia [8] explored the electrochemical reduction of D,Lhomocystine hydrochloride to the corresponding cysteine with a FM01-LC electrochemical reactor in a batch recirculation system. Electrolysis was performed at constant current, using carbon felt cathodes and DSA anodes divided by Nafion 324 cationic membranes. The experimental results were compared with a simple mathematical model to assess the effect of operative parameters (the initial substrate concentration, the reaction temperature, the current density, and the linear velocity of catholyte) on the performance. The fractional conversion of reactant, $X_{A}$ in the model, which is defined in terms of the reactant concentration in the well mixed tank initially, $c_{(0)}$ and at time $t, c_{(t)}$ as:

$X_{A}=1-\frac{c_{(t)}}{c_{(0)}}$ 
can be described by a plug flow reactor in batch recycle model for constant current electrolysis of a fixed electrolyte volume, described by Walsh [2] and demonstrated on organic electrosynthesis by Ralph et al. [9]. In the early stages of electrosynthesis of a constant volume, $V$ of electrolyte, the reaction rate is charge transfer limited and the current efficiency, $\phi$ is constant at a high value, the concentration of reactant in the tank falling linearly with time from its initial value, $c_{(0)}$ the fractional reactant conversion in the tank being described by:

$X_{A}=\frac{j \cdot A \cdot \Phi}{z \cdot F \cdot V \cdot c_{(0)}}$

After a critical time, the reactant level falls to a point where the current is equal to or exceeds the limiting current. The reaction rate is becomes mass transfer controlled and the reactant concentration in the tank decays exponentially with time according to [9]:

$\left(\ln \left[\frac{c_{(t)}}{c_{(0)}}\right]=-\frac{t}{\tau_{T}}\left[1-\exp \left(-\frac{k_{m} \cdot A}{Q}\right)\right]\right.$

where $t$ is the batch time and $\tau_{T}$ is the nominal residence time of electrolyte in the tank, i.e., the ratio of electrolyte volume in the tank, $V_{T}$ to volumetric flow rate, $Q$ :

$t_{T}=\frac{V_{T}}{Q}$

The term in square brackets on the right hand side of this equation is effectively the fractional conversion of reactant per pass through the reactor (cell) while the ratio $t / t_{T}$ is effectively the number of electrolyte recycles through the tank at time $t$.

Galia [8] has stressed the power of such a simple model and for mass transport limited batch electrolysis, and suggested an equation which expresses fractional reactant conversion in terms of dimensionless parameters:

$\ln \left(1-X_{A}\right)=-\lambda \theta+\left[\frac{\lambda}{\phi}-1-\ln \frac{\lambda}{\phi}\right]$

where $X_{A}$ is the fractional conversion of reactant, $\varphi$ is the current efficiency, $\theta$ is the dimensionless time and $\lambda$ is the ratio of limiting current under mass transport control to total current,

$\gamma=\frac{j_{L}}{j}=\frac{z \cdot F \cdot c_{b} \cdot k_{m}}{j}$

$\theta$ is the dimensionless time equal to the time elapsed divided by the total electrolysis time, $t / t_{F}$ According to Eq. (13), a plot of fractional reactant conversion, $X_{A}$ vs. $\theta$ should be linear and the slope allows the mass transfer coefficient to be calculated $[8,9]$. A comparison between the calculated trends of the conversion and the experimental values is reported in Fig. 6 as a plot of fractional reactant conversion $v s$. dimensionless time for electrolysis at a current density of 206 and $150 \mathrm{mAcm}^{-2}$; a similar agreement between predicted and experimental data was obtained for all other experiments. Some discrepancy can be observed in the mixed control region of electrical charge as the rate of decay moves from being controlled by charge transfer to mass transport, whereas the simple model predicts a sharp transition from chargetransfer control to mass-transport control. Considering that experiments were conducted under constant current conditions, the transition from one regime to the other can be very rapid if the electrode potential shifts to values significantly different from the initial value to drive the secondary reaction rapidly to supply the applied current intensity with the objective of determining the optimized conditions to perform the electrosynthesis on an

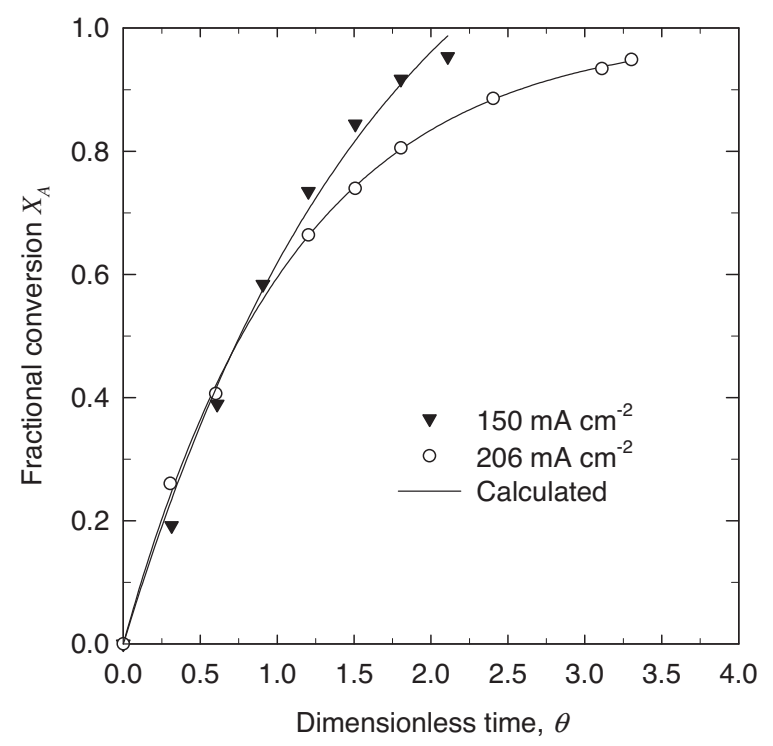

Fig. 6. Comparison of experimental data for constant current electrolysis during the batch electrosynthesis of homocysteine with the predictions of a model [9]. Experimental results are compared with those predicted from Eq. (11). After Galia [8] with modifications.

industrial scale with limited batch reaction time and costs for product isolation. The adoption of a three-dimensional electrode was beneficial [9] and the use of a carbon felt cathode [8] resulted in an efficient electrosynthesis, compared to conventional chemical routes.

An interesting electrosynthesis of the oxidation of lignins to produce vanillin, a high price food additive, on nickel mesh electrodes in batch mode and in an undivided FM01-LC flow cell reactor was reported by Smith et al. [53]. An FM01-LC flow reactor was used, over a wide range of electrolysis conditions, allowing up to $150 \mathrm{~g}$ to be electrolyzed at $<12 \mathrm{~A}$ using a variety of electrode configurations. The electrolyser operated at $145^{\circ} \mathrm{C}$ and $500 \mathrm{kPa}$ pressure in $3 \mathrm{~mol} \mathrm{dm}^{-3} \mathrm{NaOH}$ and yields of vanillin were similar to those obtained industrially using chemical oxidants (about 5 to $7 \%$ wt). Vanillin is a widely used flavouring agent in foods, drinks and pharmaceuticals. The oxidation in the flow cell was carried out using $1 \mathrm{dm}^{-3}$ of electrolyte solution containing up to $150 \mathrm{~g}$ of lignin in $3 \mathrm{~mol} \mathrm{dm}^{-3} \mathrm{NaOH}$ at $145^{\circ} \mathrm{C}, 500 \mathrm{kPa}$ (5 bar) pressure and $300 \mathrm{dm}^{3} \mathrm{~h}^{-1}$ flow rate at $<12 \mathrm{~A}$ current. The authors that cell configuration, current density and concentration of $\mathrm{NaOH}$ have negligible influence on the rate of vanillin production at the start of the electrolysis (first $100 \mathrm{~min}$ ) and note that the oxidation is favoured by the use of low current densities. A reactant conversion of $7.4 \% \mathrm{wt}$ included vanillin (5.8\%wt) and acetovanillone (1.6\%wt) products. Historically, yields in chemical and electrochemical conversions of lignins to vanillin have not exceeded $10 \%$; the results help to clarify that this apparent limit is due to an equilibrium involving formation of vanillin, its concomitant oxidative destruction or further condensation of lignins. Boiling of the aqueous electrolyte at the elevated temperature was avoided by maintaining the reactor and electrolyte circuit system under $500 \mathrm{kPa}$ ( 5 bar) pressure. These were typical working conditions in the purpose-built flow system reported in reference [53].

While most electrosyntheses have involved aqueous electrolytes or conventional organic solvents, an important exception is the specialist case of $\mathrm{N}_{2} \mathrm{O}_{4}$ oxidation to $\mathrm{N}_{2} \mathrm{O}_{5}$ in anhydrous nitric acid. The dinitrogen pentoxide in nitric acid is a highly corrosive fluid but can be used for rapid, clean nitrations of organics to realize agrochemicals and strategic energetic polymers such as HMX [54]. The electrosynthesis route to $\mathrm{N}_{2} \mathrm{O}_{5}$ was studied in a glass 


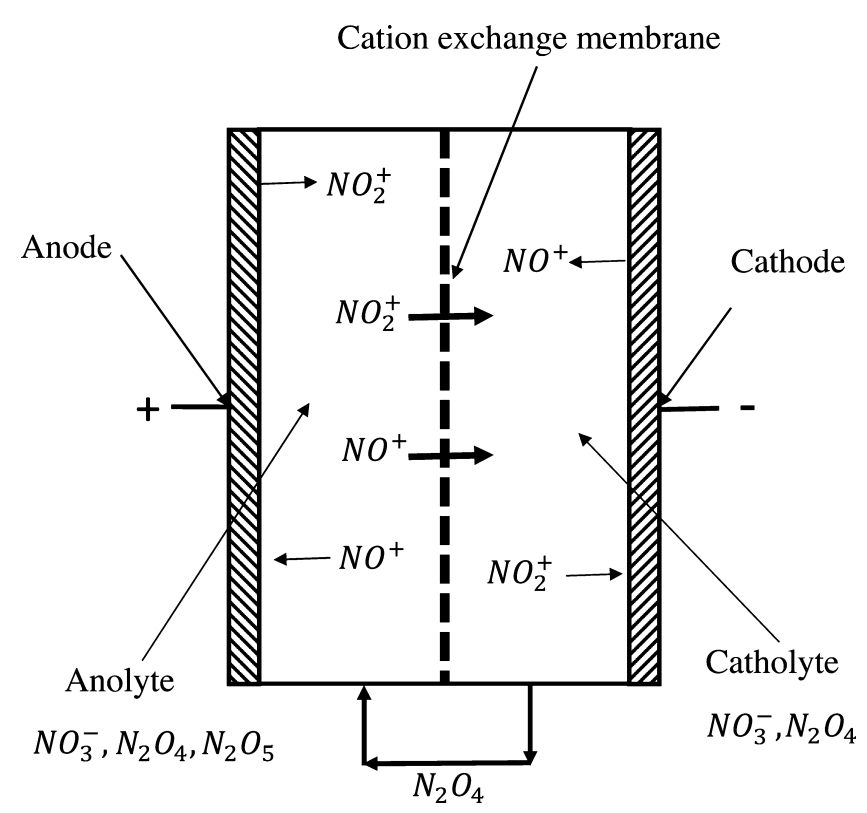

Fig. 7. The principle of dintrogen pentoxide electrosynthesis in the anode compartment of a unit cell divided by a cation exchange membrane, showing the possibility of recycling distilled $\mathrm{N}_{2} \mathrm{O}_{4}$ product from the cathode compartment back into the anode one as a reactant. After Bagg, Marshall, Schiffrin, and Walsh [20].

cell by Harrar et al. at Lawrence Livermore Laboratories in California [17] and using a laboratory flow cell by Schiffrin et al. at the University of Southampton in the early 1980s [20] (Fig. 7). Both laboratories described rectangular channel flow cells in later publications $[17,18]$. The California studies in collaboration with US state departments resulted in a 1987 patent [21] as did the Southampton activity in collaboration with the UK MOD [20]. The robust, purpose-built laboratory flow cell at the University of Southampton used a Nafion ${ }^{\circledR} 425$ cationic membrane transporting $\mathrm{NO}_{2}{ }^{+}$and $\mathrm{NO}^{+}$ions and the desired electrochemical reactions may be summarised.

At the anode : $\quad \mathrm{N}_{2} \mathrm{O}_{4}+2 \mathrm{HNO}_{3}-2 \mathrm{e}^{-} \rightarrow 2 \mathrm{~N}_{2} \mathrm{O}_{5}+2 \mathrm{H}^{+}$

(Platinised niobium is needed rather than the lower cost platinized titanium since particulate titanium can cause spontaneous decomposition of the electrolyte).

At the cathode : $\quad 2 \mathrm{HNO}_{3}+2 \mathrm{H}^{+}+2 \mathrm{e}^{-} \rightarrow \mathrm{N}_{2} \mathrm{O}_{4}+2 \mathrm{H}_{2} \mathrm{O}$

In the overall cell : $\quad 2 \mathrm{HNO}_{3}-\mathrm{H}_{2} \mathrm{O} \rightarrow \mathrm{N}_{2} \mathrm{O}_{5}$

As $\mathrm{N}_{2} \mathrm{O}_{4}$ may be formally regarded as a mixture of $\mathrm{NO}^{+}$and $\mathrm{NO}_{3}$ ions, reaction (53) may conceptually be considered as:

$\mathrm{NO}^{+}+\mathrm{NO}_{3}^{-}-2 \mathrm{e}^{-} \rightarrow 2 \mathrm{NO}_{2}^{+}$

Similarly, reaction (18) can be written as:

$4 \mathrm{H}^{+}+\mathrm{NO}_{3}^{-}+2 \mathrm{e}^{-} \rightarrow \mathrm{NO}^{+}+2 \mathrm{H}_{2} \mathrm{O}$

The overall cell reaction (17) represents the dehydration of nitric acid:

$2 \mathrm{H}^{+}+\mathrm{NO}_{3}^{-} \rightarrow \mathrm{NO}_{2}^{+}+\mathrm{H}_{2} \mathrm{O}$

The anodic oxidation of $\mathrm{N}_{2} \mathrm{O}_{4}$ in anhydrous nitric acid solution was under mixed control, requiring a good electrocatalyst and reasonable mass transfer rates. The $\mathrm{N}_{2} \mathrm{O}_{4}$ can be recycled to the anode compartment as a reactant. Oxygen evolution at the anode is a side reaction at high current densities. The $\mathrm{N}_{2} \mathrm{O}_{5}$ product may be obtained as a $<35 \%$ solution in anhydrous nitric acid or crystallised at $-20^{\circ} \mathrm{C}$ into a white solid which is kept refrigerated, stabilising it until use. In comparison to the classical methods such as ozonolysis, the electrochemical route is controllable and convenient as a strategic source of a nitrating agent which is more selective and safer than hot aqua regia reagents. Typically, the anolyte was $10 \%$ vol $\mathrm{N}_{2} \mathrm{O}_{4}$ in $\mathrm{HNO}_{3}$, at a temperature of $283 \mathrm{~K}$. The mean linear flow velocity of the electrolyte was typically $2.5 \mathrm{~cm} \mathrm{~s}^{-1}$ past the electrode surfaces, providing an average mass transport coefficient of $2.8 \times 10^{-3} \mathrm{~cm} \mathrm{~s}^{-1}$. At a current density up to $125 \mathrm{~mA} \mathrm{~cm}^{-2}$, the cell potential was $4.0-4.5 \mathrm{~V}$ and the specific energy consumption for electrolysis was typically in the range 1.0 to $1.5 \mathrm{~kW} \mathrm{~h} \mathrm{~kg}^{-1}$. At a current density of $120 \mathrm{~mA} \mathrm{~cm}^{-2}$, the cell potential of approx. $4.3 \mathrm{~V}$ consisted of catholyte, anolyte and membrane voltage drops of $0.78,0.53 \mathrm{~V}$, and 0.83 respectively. The potentials at the cathode and anode were $0.92 \mathrm{~V}$ and $-1.02 \mathrm{~V}$. The electrode overpotentials could be decreased further by the use of higher surface area coatings although dispersed particle catalytic surfaces (which might lead to decomposition of $\mathrm{N}_{2} \mathrm{O}_{5}$ ) were avoided.

In 1991, ICI Electrode Developments in the UK, in collaboration with UK Dstl, redeveloped the electrosynthesis of $\mathrm{N}_{2} \mathrm{O}_{5}$ in a purpose built, corrosion resistant FM01-LC flow assembly. This involved cell flow compartments made in PTFE with a flow recirculation loop made from fluorocarbon tube [55].

In this way, the synthesis of the polymer-based explosive nitroamine HMX (cyclotetramethylene-tetranitramine) which utilizes $\mathrm{N}_{2} \mathrm{O}_{5}$ electrosynthesis, involves recycling of aqueous nitric acid liquors. The concentration of nitric acid, leading to breaking of the $\mathrm{HNO}_{3}-\mathrm{H}_{2} \mathrm{O}$ azeotrope has been demonstrated electrodialysis research in collaboration with DERA, Fort Halstead, at the University of Bath [56]. The FM01-LC cell was divided by a nitrate ion transporting anion membrane separating a stainless steel (304 or 316) or hastelloy plate cathode and a platinized niobium lantern blade anode. 6 membranes having a thickness of 50$100 \mathrm{~mm}$ were studied. A two-compartment cell was mainly used with a high mean linear velocity of electrolyte $\left(66 \mathrm{~cm} \mathrm{~s}^{-1}\right)$ and a PTFE mesh turbulence promoter in each compartment; a threecompartment one was also considered. The main cathode reaction was nitrate ion reduction (with hydrogen evolution as a secondary reaction) while water oxidation to oxygen occurred at the anode. The initial concentration of both compartments was typically $65-70 \%$ After batch electrolysis at a current density of $300 \mathrm{~mA}$ $\mathrm{cm}^{-2}$, anolyte concentrations could be as high as $77 \%$, well above the azeotrope of $68.5 \%$ with the catholyte falling to as low as $25 \%$ $\mathrm{HNO}_{3}$. Different anionic membranes were compared and showed an energy consumption range of $1.4-4.7 \mathrm{~kW} \mathrm{~h} \mathrm{~kg}^{-1}$ of nitric acid. Among the membranes tested, the Raipore 6030 (Pall) membrane showed the highest current efficiency and selectivity for nitrate ions at a constant current density of $300 \mathrm{~mA} \mathrm{~cm}^{-2}$.

The FM01-LC reactor has also been used to carry out electrowinning in the mining industry. Lapidus et al. [57] presented a novel process for the extraction and recovery of gold and silver from minerals and other materials, based on partially oxidized thiourea. In the first stage, formamidine disulfide (FADS) is produced by the controlled anodic oxidation of thiourea. In Fig. 8, the production of FADS data are shown for the first four cycles (oxidation of the original solution and three re-oxidations) of a solution that had been contacted with fresh pretreated concentrate [57]. Every $10 \mathrm{~min}$, samples were withdrawn to evaluate the FADS produced as well as the irreversible thiourea degradation.

The behaviour was similar in all cases ( $14 \%$ thiourea conversion to FADS with $<0.5 \%$ degradation), except for the last $10 \mathrm{~min}$ of the third oxidation, where an unusually large potential was detected at one point in the reactor. However, this situation did not recur in subsequent reoxidation. The resultant solution was used to leach a 


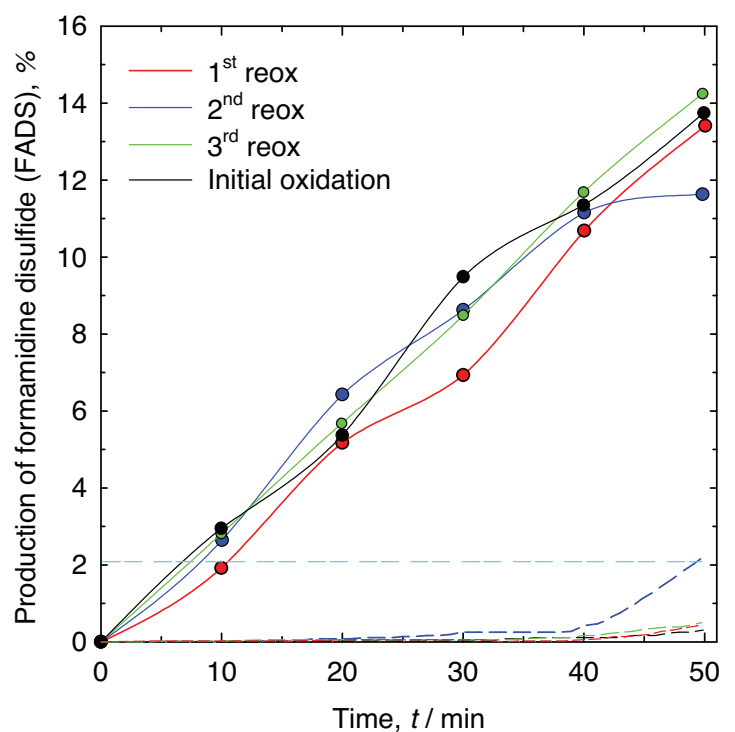

Fig. 8. Successive oxidations of the thiourea solution and degradation of formamidine disulphide. The continuous lines represent the percentage of thiourea conversion to FADS and the dotted lines show the percentage of irreversible thiourea degradation. After Lapidus-Lavine, González, Nava, Benavides and Lara-Valenzuela [57].

solid phase, containing the precious metals. Once the values are extracted and the solids separated, the pregnant solution is introduced into the cathodic compartment of the same electrochemical reactor for reduction and recovery of the metallic ions. During the leach/recovery cycles [57] a similar amount of silver was leached, $700-800 \mathrm{ppm}$, which corresponds to $35-40 \%$ contained in the concentrate. This demonstrates that the leaching capacity of thiourea solution was not impaired by the accumulation at these levels (200 ppm Fe, $100 \mathrm{ppm} \mathrm{Zn}$ and $80 \mathrm{ppm} \mathrm{Cu}$ ), although it can be expected, and was observed in other studies (not shown here) that higher values would adversely affect the efficiency of the overall process. Approximately $85 \%$ of the dissolved silver was recovered.

Once valuable metals had been recovered, the solution was recycled to the anodic compartment for re-oxidation. Energy requirements are optimized since the same current employed to produce the FADS is used to electrodeposit the precious metals. The process has been successfully applied to a variety of minerals, concentrates and materials and is currently being operated on a 1 t day $^{-1}$ pilot scale [57].

\subsection{Electrowinning, metal ion removal and recycling}

Electrochemical reactors used for metal recovery have seen continuous improvement in design and performance over the last three decades $[26,27,58]$ and they represent a viable, if specialized, option to selectively recover pure metals in its most valuable metallic form. Some metal ion reactions have been studied in FM01-LC, in order to carry out metal recovery with high yields and avoid side reactions (because uniform potential distribution of this electrochemical reactor).

Reyes-Cruz, González, and Oropeza [10] carried out gold and silver recovery from a leaching solution using a FM01-LC laboratory cell, with a reticulated vitreous carbon cathode. A systematic voltammetric study developed in this reference allows the determination of the potential range at which the selective deposition of gold and silver is carried out in the presence of a high content of copper. As a first approach, laboratory solutions prepared with a high content of cyanide and copper and low values of gold and silver are used; later, the methodology is applied to leaching solutions of industrial origin. The chemical speciation and microelectrolysis studies showed that copper deposition occurs at more negative potentials than deposition of gold and silver. The deposition of gold and silver was not interfered with by the high concentration of $\mathrm{Cu}(\mathrm{I})$ ions when the leaching solution was electrolyzed in a laboratory electrochemical reactor FM01-LC with a reticulated vitreous carbon (RVC) cathode. Fig. 9(a and b) show the evolution in the concentration of the $\mathrm{Au}(\mathrm{I})$ and $\mathrm{Ag}(\mathrm{I})$ ions with time when the electrolysis was carried out at $-1.4 \mathrm{~V} v \mathrm{~s}$. SCE.

Depletions in the concentration of $\mathrm{Au}(\mathrm{I})$ and $\mathrm{Ag}(\mathrm{I})$ were up to $48 \%$ and $71 \%$, respectively, from their original concentrations. The concentration of $\mathrm{Cu}(\mathrm{I})$ was constant during the first $10 \mathrm{~min}$ of electrolysis, however, in the following $25 \mathrm{~min}$, the concentration of $\mathrm{Cu}(\mathrm{I})$ fell by $7 \%$ (Fig. 9c). The morphology and composition of gold, silver and copper deposits on the RVC was analyzed by scanning electron microscopy (SEM) and energy dispersive X-ray studies of the electrode surface finding metallic $\mathrm{Ag}$ and $\mathrm{Au}$ in high composition and remaining amounts of $\mathrm{Cu}$. The presence of copper is consistent with the depletion of this ion observed after 25 min of electrolysis in Fig. 9c. When the concentrations of $\mathrm{Au}(\mathrm{I})$ and $\mathrm{Ag}(\mathrm{I})$ ions diminished in the solution, the deposition of $\mathrm{Cu}(\mathrm{I})$ became energetically favourable. Under these conditions, the electrolysis should be stopped before the deposition of copper begins if a quantitative separation of gold and silver is wanted. Chemical speciation and cyclic voltammetry confirmed that the codeposition of $\mathrm{Ag}$ and $\mathrm{Au}$ occurred within the potential range of $-1.2 \mathrm{~V}$ vs. SCE to $-1.5 \mathrm{~V}$ vs. SCE. At potentials less negative than $-1.5 \mathrm{~V} v s$. SCE, the hydrogen evolution took place. Hence, the authors of reference [10] selected $-1.4 \mathrm{~V} v$ s. SCE to recover gold and silver assuming a mass transport controlled process avoiding the hydrogen evolution reaction.

Terrazas-Rodriguez et al. [11] carried out the electrochemical treatment of solutions from spent automotive catalyst leachings in order to recover palladium. The electrolyte solution consisted on a mixture of $\mathrm{Rh}^{3+}, \mathrm{Pd}^{2+}$ and $\mathrm{Nd}^{3+}$ ions at 100,500 and $1200 \mathrm{ppm}$, respectively, in $1 \mathrm{~mol} \mathrm{dm}^{-3}$ nitric acid and $298 \mathrm{~K}$. The separation of palladium from this mixture by electrodeposition was carried out using the FM01-LC parallel plate reactor with stainless steel cathode (and the other being a rotating cylinder electrode). The study, involving an electrolyte containing a $0.94 \mathrm{~mol} \mathrm{dm}^{-3}$ initial

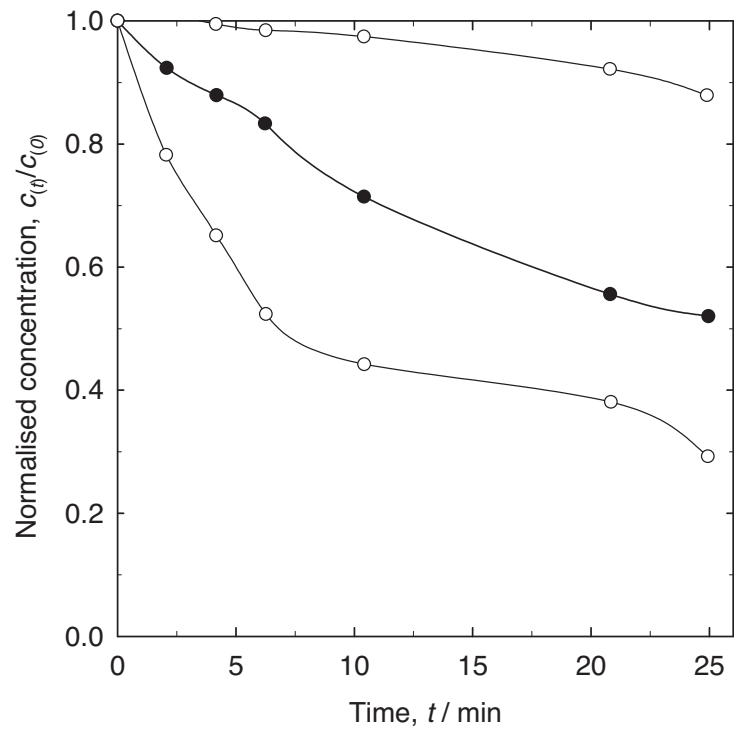

Fig. 9. Electrochemical recovery of: a) gold, b) silver and c) copper from a leaching effluent, using FM01-LC electrochemical reactor. After Reyes-Cruz, González, and Oropeza [10]. 
palladium concentration in $1 \mathrm{~mol} \mathrm{dm}^{-3}$ nitric acid or $1 \mathrm{~mol} \mathrm{dm}^{-3}$ hydrochloric acid at $25^{\circ} \mathrm{C}$, was carried out at mean linear flow velocities of $1.27<v<11.36 \mathrm{~cm} \mathrm{~s}^{-1}\left(120<R e=v d_{e} / v<1080\right)$.

The morphology of the palladium deposits at the entrance and at the exit of the electrolyte compartment of the FM01-LC reactor showed the effect of the manifold distributors during the electrolysis; the manifolds generate micro turbulences, increasing the mass transport coefficient in these areas and favouring rapid recovery of palladium ions. The cumulative current efficiency during 99\% removal of $\mathrm{Pd}^{2+}$ ions from solution in the parallel plate electrode reactor was $35 \%$. The volumetric energy consumption during the electrolysis was $2.1 \mathrm{~kW} \mathrm{~h} \mathrm{~m}^{-3}$ for metal recovery. Using a three-dimensional stainless steel electrode in the FM01-LC laboratory reactor, $99 \%$ of palladium ions were recovered after 30 min of electrolysis.

Several studies of metal electrowinning have been performed. Gonzalez-Perez et al. [59] reported a fundamental study of the electrochemical deposition of cadmium and zinc contained in solutions from a zinc electrorefining plant. The initial concentrations of cadmium and zinc were 12,283 and 51,533 ppm, respectively). This reference also analyzes the performance of a filter press electrochemical reactor used in the recovery of zinc and cadmium from this effluent. The cathodic polarization indicated an electrochemical processes under mixed control at 304 SS and Al cathodes. The cyclic voltammetry studies on stainless steel revealed the presence of metal deposits at low current densities, whereas $\mathrm{Zn}$ and $\mathrm{Cd}$ were preferentially deposited at high overpotentials.

The recovery of zinc and cadmium was carried out in FM01-LC electrolyser on stainless steel cathode at $180 \mathrm{~min}$ and $\mathrm{Al}$ cathode at 300 min. The greatest recovery of cadmium (19\%) and zinc (24\%) at a current density of $4 \mathrm{mAcm}^{-2}$ was obtained with an AISI 304 grade stainless cathode at $t=180 \mathrm{~min}$. Despite the increase in cadmium removal when an $\mathrm{Al}$ cathode is used, the removal of zinc appeared to be smaller than with a 304 stainless steel cathode. This is attributable to the tendency for the freshly deposited zinc to redissolve at longer electrolysis times. Additional experiments with 304 stainless steel for a 300 min electrolysis supported this statement.

The SEM micrographs of cathode plates confirmed the presence of cadmium and zinc deposits. Energy dispersive x-ray analysis revealed that the composition of such deposits depends on the deposition time and the cathode material. A continuous filter press electrochemical reactor with 304 stainless steel and aluminium cathodes exhibited a promising performance level for cadmium and zinc recovery from industrial solutions.

During the routine electroplating of chromium from chromic acid baths, substrate metals such as iron, copper and zinc gradually dissolve and the $\mathrm{Cr}(\mathrm{VI})$ content decreases as $\mathrm{Cr}(\mathrm{III})$ ions build up. These contaminants result in deterioration of the chromium deposit, which can suffer from roughness, pitting, and reduced wear resistance, while the cathode efficiency for chromium deposition can drastically decrease. The chromic acid bath may be treated by a combination of controlled, cascade water rinse/air extraction system and electrodialysis (Fig. 10) [1] to produce minimum effluent and an electroplating solution, which has depleted iron, copper and zinc (removed at the cathode of the electrodialysis cell) and regenerated $\mathrm{Cr}(\mathrm{VI})$ (at the anode). Laboratory trials were conducted at $20-50 \mathrm{mAcm}^{-2}$ in a $64 \mathrm{~cm}^{2}$ FM01-LC cell, allowing suitable membranes to be studied in a unit electrodialysis cell which facilitated simultaneous $\mathrm{Cr}(\mathrm{VI})$ regeneration at the lead anode and electrodialysis of transition metal ions through a cation fluorocarbon membrane (Nafion 450) to deposit as metal on the stainless steel cathode. This work facilitated scaleup to a pilot cell stack which was constructed and operated at Poeton Industries (Gloucester, UK). The electrodialysis stack was

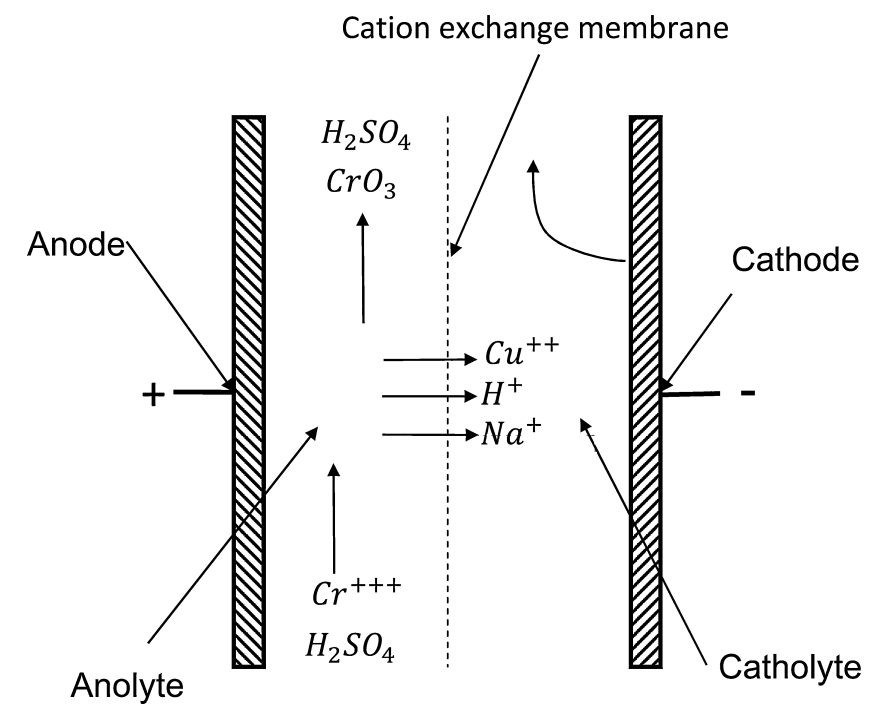

Fig. 10. Regeneration of chromic acid electroplating baths, showing the principle of removal of dissolved copper, zinc, and iron by electrodialysis together with oxidation of $\mathrm{Cr}^{3+}$ to regenerate $\mathrm{Cr}(\mathrm{VI})$. After Walsh [1].

divided by fluorocarbon-based cation-exchange membranes (Nafion 450) and contained 12 lead anodes and cathodes, each $0.12 \mathrm{~m}^{2}$ in area. The typical current density was $200-500 \mathrm{~A} \mathrm{~m}^{-2}$. The electrodialysis stack was installed into a recycle loop on the chromic acid $\left(55^{\circ} \mathrm{C}, 1400 \mathrm{dm}^{3}\right)$ process tank and allowed a reduction in effluent waste of around 500 litres per day, a $70 \%$ reduction in water consumption and an $80 \%$ reduction in chromium loss. The trivalent chromium levels in the plating bath were maintained at levels down to $2-6 \mathrm{~g} \mathrm{dm}^{-3}$ while the iron contamination was kept below $3 \mathrm{~g} \mathrm{dm}^{-3}$. Over a four-month period, the electrodialysis unit was estimated to have removed $112 \mathrm{~kg}$ of trivalent chromium and $20 \mathrm{~kg}$ of dissolved iron [60].

\subsection{Electrochemical degradation of organics for environmental treatment}

The oxidation of organic compounds is carried out by 2 mechanisms in a filter press-type reactor, by direct and indirect oxidations. Indirect oxidation of organic compounds can be achieved, by means of in-situ generation of strong oxidants such as $\mathrm{Cr}_{2} \mathrm{O}_{7}{ }^{2-}, \mathrm{Ce}^{4+}, \mathrm{Fe}^{3+}$ and $\mathrm{Ag}^{2+}[61]$.

Several studies of these in-situ generated reagents have utilized the FM01-LC reactor. Roussel [62] studied the indirect oxidation of 4-anisaldehyde (PMA) into 4-methoxytoluene (PMT) mediated by means of anodically generated $\mathrm{Ce}^{4+}$ ions. The oxidation was carried out in a batch recycle system with aqueous, acidic cerium methanosulfonate solution. An undivided cell with a Pt-Ti mesh anode and three-dimensional porous graphite cathode was selected to achieve the anodic oxidation of PMT. The performance of the FM01-LC electrolyser was investigated at different acidities, temperatures and current densities and conversion of PMT. The highest yield of PMA (28\%) was obtained at a temperature of $30^{\circ} \mathrm{C}$, an acidity of $0.2 \mathrm{~mol} \mathrm{dm}^{-3}$ and a current density of $300 \mathrm{~mA} \mathrm{~cm}^{-2}$ with a PMT conversion of $10 \%$.

Direct oxidations has been extensively applied to effluent treatment from textile industries as well as chemical, plastics and other industries generate effluent fluids with high concentrations of organic compounds, among which the most present are azo dyes and cresols that are recalcitrant to mineralization by traditional biological and physicochemical methods [12]. Incineration of cresols requires very strong oxidants, such as hydroxyl radicals 
$\left({ }^{\bullet} \mathrm{OH}\right)$. The generation of ${ }^{\bullet} \mathrm{OH}$ can be obtained by direct oxidation of water.

Nava et al. [12] carried out a comparative study of the incineration of 2-mM p-cresol and o-cresol in $1 \mathrm{M}-\mathrm{H}_{2} \mathrm{SO}_{4}$ in aqueous media. Electrochemical formation of hydroxyl radicals was determined by microelectrolysis. They indicated that both the p-cresol and o-cresol oxidation were carried out via hydroxyl radicals $\left({ }^{\circ} \mathrm{OH}\right)$ formed by water oxidation at the boron-doped diamond (BDD)- $\mathrm{H}_{2} \mathrm{O}-\mathrm{H}_{2} \mathrm{SO}_{4}$-p-cresol and o-cresol interface. In both cases, the potential ranges for significant hydroxyl radical formation, were between $2.3 \mathrm{~V} \leq \mathrm{E} \leq 2.75 \mathrm{~V} v$ s. SHE and the current density was $10 \mathrm{~mA} \mathrm{~cm}^{-2}$.

Electrolysis in an undivided FM01-LC reactor with 2-D BDD electrodes were performed at different Reynolds values $27,129 \leq R e \leq 42,631$ at a current density of $10 \mathrm{mAcm}^{-2}$ chosen from microelectrolysis studies. Fig. 11 shows values of global reaction rate for o-cresol and $\mathrm{p}$-cresol and it is compared with mass transport coefficients evaluated with Eq. (7) (the coefficients being considered for a channel containing a PTFE mesh turbulence promoter) in the same $R e$ range.

$S h=0.56 \operatorname{Re}^{0.62} S c^{0.33}$

The degradation kinetics for both substances depends on the Reynolds number even if the oxidation velocity of p-cresol in Fig. 11a) is greater than that of o-cresol in Fig. 11b). The values of the mass transport coefficient obtained with Eq. (2) in Fig. 11c) were two orders of magnitude larger than those obtained for either of the two cresols This indicates that p-cresol and o-cresol degradation is not completely controlled by mass transport, since it involves a complex mechanism. The rate of degradation was slow for p-cresol and o-cresol, however it increases slightly as a function of the $R e$, indicating that the oxidation involves a complex pathway; current efficiency also rises as a function of the Re. For p-cresol, the mineralization at $R e=42,631$ reached $90 \%$, with $71 \%$ current efficiency and an energy consumption of $7.8 \mathrm{kWh} \mathrm{m}^{-3}$; whereas o-cresol was mineralized to $84 \%$, with $67 \%$ current efficiency and an energy consumption of $6.6 \mathrm{~kW} \mathrm{~h} \mathrm{~m}^{-3}$. The results

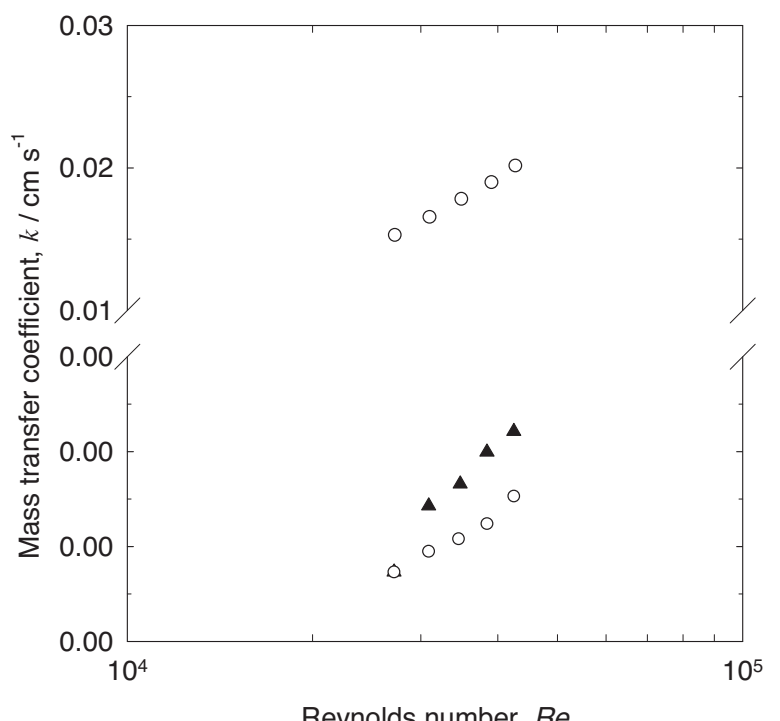

Fig. 11. Values of global reaction rate for a) p-cresol and b) o-cresol. The global reaction rates are compared with c) mass transport coefficients considering fully developed flow. After Nava, Núñez, and González [12]. obtained in this work demonstrated that o-cresol is more recalcitrant than p-cresol.

The FM01-LC reactor has been evaluated for electrochemical incineration of other recalcitrant compounds, for example vinasse. In 2008, Nava et al. [63] showed the convenience of electrochemical degradation of vinasse in an FM01-LC reactor using 3-D BDD electrodes. With this configuration, the flow hydrodynamics enhanced hydroxyl ion-organic contact at the BDD surface, which increases organic mineralization efficiency. Although it is well known that three-dimensional electrodes improve space-time yield, such electrode configurations have rarely been reported for complete electrochemical oxidation of organic contaminants. In this work, 3-D BDD (mesh-BDD) electrodes are introduced for mineralization of a synthetic vinasse.

Electrolysis was carried out at $R e$ values between 22 and 109 at $10 \mathrm{~mA} \mathrm{~cm}^{-2}$ during $480 \mathrm{~min}$. The value of current density was selected in order to maintain the electrode potential within the interval of 2.3 to $2.75 \mathrm{~V} \mathrm{vs}$. SHE, which favors ${ }^{\circ} \mathrm{OH}$ radical formation. The Re values were smaller than those used for 2-D BDD electrodes, since mesh-BDD electrodes improves space-time yield, promoting better interaction between $\operatorname{BDD}\left({ }^{\bullet} \mathrm{OH}\right)$ and vinasse than those obtained with the other organic molecules. The use of a relatively low electrolyte flow velocity was chosen to minimise desorption of $\left({ }^{\bullet} \mathrm{OH}\right)$ at the 3-D electrode surface.

Another example of electrochemical incineration of recalcitrant organics was presented by Coria et al. [64]. Degradation of the antiinflammatory drug diclofenac was achieved by electrochemical oxidation in $\mathrm{NaClO}_{4}$ at a neutral pH using an FM01-LC reactor equipped with a boron doped diamond electrode. Microelectrolysis was carried out to find the current density range in which hydroxyl radical $\left({ }^{\circ} \mathrm{OH}\right)$ formation is favoured as $10 \leq j \leq 20 \mathrm{~mA}$ $\mathrm{cm}^{-2}$. The electrolysis experiments at mean linear flow velocities of $14.6 \leq v \leq 58.4 \mathrm{~cm} \mathrm{~s}^{-1}$ were performed at $15 \mathrm{mAcm}^{-2}$ during 240 min. The diclofenac kinetics not show dependence with hydrodynamics owing to hydroxyl-organic contact at the BDD surface is minor $[65,66]$. At the mean linear flow velocities concerned $\left(41.1 \leq v \leq 58.4 \mathrm{~cm} \mathrm{~s}^{-1}\right)$ the hydrodynamics do not influence the mineralization rate of diclofenac. Complete mineralization was only achieved when the flow rate was increased to $29.2 \mathrm{~cm} \mathrm{~s}^{-1}$. The experimental arrangement achieved $100 \%$ diclofenac mineralization with $78 \%$ current efficiency and an energy consumption of $2.54 \mathrm{~kW} \mathrm{~h} \mathrm{~m}^{-3}$ at a current density of $15 \mathrm{~mA} \mathrm{~cm}^{-2}$ and a linear electrolyte velocity of $29.2 \mathrm{~cm} \mathrm{~s}^{-1}$.

An important field of application of the FM01-LC cell is the degradation of waste waters from textile industries that contains several types of dyes mainly. Several studies have been performed on removal of such persistent organic contaminants. Butrón et al. [65] Performed electrochemical incinerations of indigo were carried out in the FM01-LC cell using 2-D BDD electrodes at a current density of $5.3 \mathrm{~mA} \mathrm{~cm}^{-2}$. The electrolysis was performed at $R e$ numbers between 1,600 and 18,300. The range of $R e$ numbers employed for indigo was different to that used in [12] $(27,100$ to $42,600)$ which is attributable to the different interactions between $\operatorname{BDD}\left({ }^{\bullet} \mathrm{OH}\right)$ and organic molecules. Fig. 12(a) shows the normalized colour (at an absorption maximum wavelength of $639 \mathrm{~nm}$ ) and (b) COD results obtained from experiments per-formed at a constant current density $\left(5.3 \mathrm{~mA} \mathrm{~cm}^{-2}\right)$ and variable $R e$ numbers. In these figures, the normalized colour and COD decreases with the time at the different Re values. However, colour and COD depletion did not show marked improvement at the elevated Re numbers. The fact that the higher electrolyte flow rate did not improve the rate of indigo oxidation and colour removal may be due to the complex mechanism of indigo degradation. The electrolysis was carried out in an undivided FM01-LC cell, in which the degradation of indigo may also occur at the cathode $(\mathrm{Pt} / \mathrm{Ti})$ due to hydrogen peroxide production: 
(a)

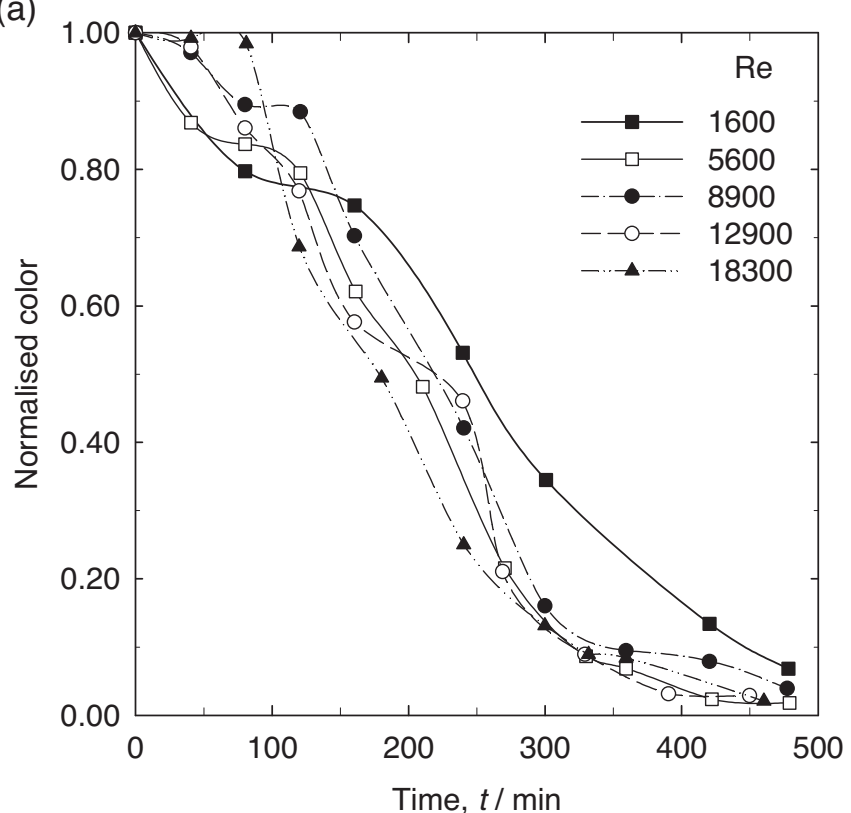

(b)

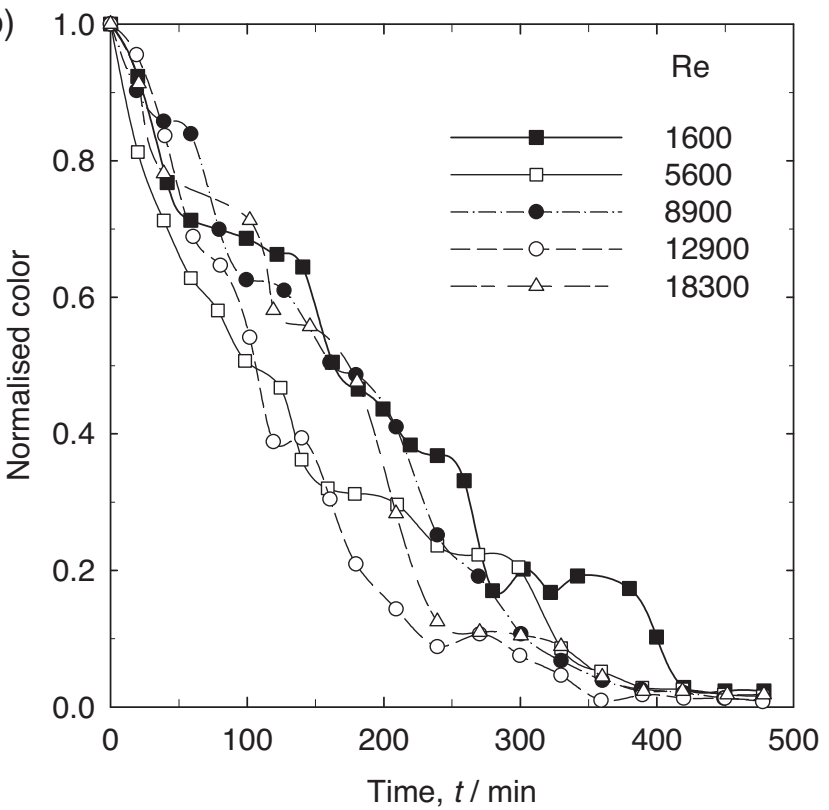

Fig. 12. Typical concentration vs. time decay of a) colour and b) COD decay during the electrolysis of indigo on BDD in the FM01-LC electrolyser. Electrolyte composition: $1 \times 10^{-3} \mathrm{~mol} \mathrm{dm}^{-3}$ indigo in $0.05 \mathrm{~mol} \mathrm{dm}^{-3} \mathrm{NaCl}$ at $25^{\circ} \mathrm{C}$. The electrolyte was chosen to resemble a synthetic denim laundry wastewater. Current densities: (a) 5.3 and (b) $15 \mathrm{~mA} \mathrm{~cm}^{-2}$. Reynolds numbers are shown. After Butrón, Juárez, Solís and Teutli [65].

$\mathrm{O}_{2}(\mathrm{~g})+2 \mathrm{H}^{+}+2 e^{-} \rightarrow \mathrm{H}_{2} \mathrm{O}_{2}$

The range of current efficiencies was between 0.7 and 1.2, which was higher than the values reported in the literature for similar dyes (ca. 0.2 ). Values of current efficiency over $100 \%$ indicate that byproducts of direct oxidation assist the colour and COD removal together with hydroxyl radicals.

Since BDD electrodes are expensive compared to other electrode materials [67], lower cost electrodes, for example DSA anodes, have been evaluated. López et al. [68] reported the incineration of $1 \times 10^{-3} \mathrm{~mol} \mathrm{dm}^{-3}$ indigo textile dye $(536 \mathrm{ppm}$ COD) in $0.05 \mathrm{~mol} \mathrm{dm}^{-3} \mathrm{NaCl}$ aqueous media (which resembles a denim laundry industrial wastewater). Electrolysis studies indicated that oxidation of indigo dye was carried out via hydroxyl radicals $\left({ }^{\circ} \mathrm{OH}\right)$ formed by water oxidation on the mesh-DSA $\left(\mathrm{Ti} / \mathrm{IrO}_{2}-\mathrm{SnO}_{2}-\mathrm{Sb}_{2} \mathrm{O}_{5}\right)$ electrode. Electrolysis in a $\mathrm{FM01-LC}$ reactor were performed at Reynolds between $50<R e<300$, and a fixed current density of $7 \mathrm{mAcm}^{-2}$ (obtained from microelectrolysis experiments).

The experimental arrangement achieved $100 \%$ colour removal, mineralization of indigo and $80 \%$ current efficiency. The rate of degradation of indigo was not a function of the hydrodynamics, proving that this process is not controlled by mass transport. The FM01-LC cell equipped with mesh-DSA improves space-time yield, allowing better interaction between ${ }^{\circ} \mathrm{OH}$ generated at the DSA surface and organics, a phenomenon that increases organic mineralization efficiency.

Another example of anodic degradation of indigo blue was reported by Nava et al. [69]. This compared the performance of 2-D (plate) and 3-D (mesh) boron-doped diamond (BDD) on titanium electrodes, fitted into a filter-press reactor, during the electrochemical incineration of indigo textile dye as a model organic compound in chloride medium. Electrolysis was carried out in the FM01-LC reactor at mean fluid velocities between $0.9 \leq v \leq 10.4$ $\mathrm{cm} \mathrm{s}^{-1}$ and $1.2 \leq v \leq 13.9 \mathrm{~cm} \mathrm{~s}^{-1}$ for the 2-D BDD and the 3-D BDD electrodes, respectively, at current densities of 5.63 and $15 \mathrm{~mA}$ $\mathrm{cm}^{-2}$. As was expected, the COD values decreased as a function of the electrical charge passed during the electrolysis but COD decay did not undergo a marked improvement with increasing electrolyte velocity; the mean fluid velocity does not seem to alter the mineralization process in the case of the planar BDD. The results obtained in [70] appear similar, with a small dependence of COD decay on the velocity, although progressive COD abatement required a higher amount of charge passed for the 3-D BDD anode.

The results employing 3-D BDD anode are worth highlighting, since they are opposite to what would be expected. Indeed, it is well known that 3-D electrodes tend to improve the space-time yield contact between $\operatorname{BDD}\left({ }^{\bullet} \mathrm{OH}\right)$ and the organics within porous electrodes, thus increasing the mineralization current efficiency [10]. Nevertheless, the 3-D BDD electrode led only to a partial degradation of the organic compound (ca. 94\%) after a charge of $7.5 \mathrm{~A} \mathrm{~h} \mathrm{dm}^{-3}$ using a linear electrolyte flow velocity of $4.3 \mathrm{~cm} \mathrm{~s}^{-1}$, whereas the 2- BDD led to the complete mineralization of indigo at a linear electrolyte flow velocity of $7.3 \mathrm{~cm} \mathrm{~s}^{-1}$ after an electrical charge of $2.2 \mathrm{~A} \mathrm{~h} \mathrm{dm}^{-3}$. The best electrolysis performance for the 3-D BDD electrode was obtained at the second mean fluid velocity $\left(4.3 \mathrm{~cm} \mathrm{~s}^{-1}\right)$, whereas at higher velocities values the COD removal was slower. This can be probably be attributed to the progressive enhancement of undesired desorption of hydroxyl radicals from the BDD surface as the degree of turbulence increased at high electrolyte flow velocity.

Rangel et al. [13] showed the convenience of degrading Reactive Blue 222 dye using planar BDD electrodes stacked in a FM01-LC reactor. Electrochemical oxidation of reactive blue $222\left(1.6 \times 10^{-3}\right.$ mol dm $\left.{ }^{-3} ; 1300 \mathrm{mg} \mathrm{dm}^{-3} \mathrm{COD}\right)$ in $0.5 \mathrm{~mol} \mathrm{dm}^{-3} \mathrm{Na}_{2} \mathrm{SO}_{4}$ aqueous media (which resembles a textile wastewater) on a boron-doped diamond electrode (BDD) was studied, using bulk electrolysis. The influence of current density and hydrodynamics was investigated. The depletion of COD during the Reactive Blue 222 electrochemical oxidation at mean linear flow velocity of 73 and $146 \mathrm{~cm} \mathrm{~s}^{-1}$ showed a slight improvement with flow velocity due to the process no longer being limited by mass transport. The use of such high velocities is unusual as it incurs a relatively high pressure drop over the flow channel and it is unclear why such a high velocity was used. Electrolysis with a BDD electrode at $20 \mathrm{~mA} \mathrm{~cm}^{-2}$ and mean linear flow velocity of $146 \mathrm{~cm} \mathrm{~s}^{-1}$ was the only experiment that led to $100 \%$ mineralization of Reactive Blue 222 , with an energy consumption of $11.8 \mathrm{~kW} \mathrm{~h} \mathrm{~m}^{-3}$ and an integral current efficiency of $70 \%$. 
There is a clear need to study the remediation of more realistic textile and dye effluents in flow cells since these often have a complex and time-dependent composition rather than the simple supporting electrolytes considered in the above studies.

\subsection{Flow batteries and fuel cells for energy conversion and storage}

Energy storage systems are becoming increasingly important as an essential component in power efficiency and distribution systems. Large-scale energy storage devices will be required for full and effective integration of renewable sources (e.g., wind and solar-systems) into the current production/distribution networks. Redox flow batteries have been proposed as one solution to energy storage and load levelling problems. A number of redox couples have been proposed for use within large-scale flow batteries. Operational technologies include bromine/polysulfide, all vanadium, zinc/bromine, zinc/cerium [15,71], borohydride [13] and soluble lead-acid $[14,72]$. The need to scale-up this type of battery (power capacity and current density is proportional to electrochemical cell size), lead to the use of a flexible, controlled flow cell.

Ponce de León et al. [14] evaluated a sodium borohydride hydrogen peroxide liquid electrolyte fuel cell on a bench scale using the FM01-LC reactor. The electrode reactions are:

At the anode, borohydride ions oxidise to metaborate ions in alkaline solution:

$\mathrm{BH}_{4}^{-}+8 \mathrm{OH}^{-}=\mathrm{BO}_{2}^{-}+6 \mathrm{H}_{2} \mathrm{O}+8 \mathrm{e}^{-} \quad E_{a}^{o c}=-1.24 \mathrm{~V}$ vs.SHE

At the cathode, peroxide ions in an acid electrolyte, reduce to water

$\mathrm{H}_{2} \mathrm{O}_{2}^{-}+2 \mathrm{H}^{+}+2 \mathrm{e}^{-}=2 \mathrm{H}_{2} \mathrm{O} \quad E_{c}^{o c}=-1.77 \mathrm{~V}$ vs.SCE

Providing an overall cell reaction of:

$\mathrm{BH}_{4}^{-}+4 \mathrm{H}_{2} \mathrm{O}_{2}=\mathrm{BO}_{2}^{-}+6 \mathrm{H}_{2} \mathrm{O}+8 \mathrm{e}^{-} \quad E_{\text {cell }}^{o c}=3.01 \mathrm{~V}$

An arrangement of 2 and 4 cell stacks was operated in the divided mode. Commercially available electrodes were used; the cathode was a porous carbon paper of $5 \mathrm{~cm} \times 16 \mathrm{~cm} \times 0.03 \mathrm{~cm}$ thickness printed with a Pt-on-carbon black catalyst while the anode was a carbon cloth of $5 \mathrm{~cm} \times 16 \mathrm{~cm}$ and $0.05 \mathrm{~cm}$ thickness with a $10 \%$ wt. Au loading on carbon black (Vulcan XC-72). The projected area of each electrode facing the electrolyte was $64 \mathrm{~cm}^{2}$ $(16 \mathrm{~cm} \times 4 \mathrm{~cm})$, Typically, the anolyte was $1 \mathrm{dm}^{3} 25 \%\left(6 \mathrm{~mol} \mathrm{dm}^{-3}\right)$ sodium borohydride in $6 \mathrm{~mol} \mathrm{dm}^{-3} \mathrm{NaOH}$ and the catholyte was $1 \mathrm{~mol} \mathrm{dm}^{-3}$ hydrogen peroxide in $1 \mathrm{~mol} \mathrm{dm}^{-3} \mathrm{HCl}+3 \mathrm{~mol} \mathrm{dm}^{-3}$ $\mathrm{NaCl}$ solution at 20,40 and $60^{\circ} \mathrm{C}$. A volumetric flow rate of $95 \mathrm{dm}^{3} \mathrm{~h}^{-1}$ was used in all the experiments corresponding to a mean linear flow velocity of $12.0,6.0$ and $3.0 \mathrm{~cm} \mathrm{~s}^{-1}$ in the unit cell, two-cell and four-cell stacks, respectively.

Fig. 13 shows the power density and cell voltage for single stack. The load was applied in steps of $0.25 \mathrm{~A}$ within the range of $0-5 \mathrm{~A}$. Each step lasted $1 \mathrm{~min}$ and the current was continuously applied from one value to the next without disconnecting the cell. The cell potential curve shows an open circuit value of $1.9 \mathrm{~V}$. In acidic solution, the theoretical cell potential should be ca. $3 \mathrm{~V}$, since the reduction of peroxide in acid has an electrode potential of $1.77 \mathrm{~V} v \mathrm{~s}$. SHE. The experimental cell potential, however, is closer to $2.11 \mathrm{~V}$, which is the value of the borohydride-peroxide cell when peroxide is reduced in alkaline solution. The cell potential dropped as the current increases; at $10 \mathrm{mAcm}^{-2}$, the cell potential decreased around $0.2 \mathrm{~V}$ and continued to decay linearly with current density, showing a strong dependence on the ohmic resistance of the cell. Overpotentials due to kinetic limitations are added to by ohmic drop through membrane and gas generation during electrolyte decomposition. In the constant current experiment drawing $2 \mathrm{~A}$ from the fuel cell, the resistance increased from $0.15 \mathrm{ohm}$ at the

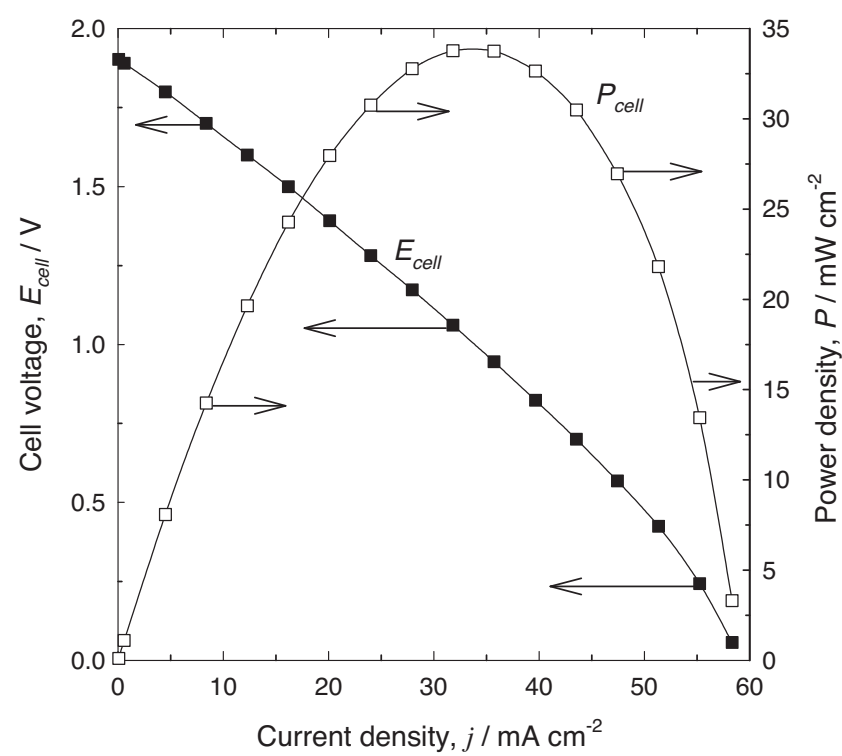

Fig. 13. Current density vs. power density for a borohydride-peroxide energy storage system. After Ponce de León, Walsh, Rose, Lakeman, Browning and Reeve [14].

start up to $0.25 \mathrm{ohm}$ after $3500 \mathrm{~s}$. The ohmic losses are attributable blocking of the membrane by anodic oxidation products, mainly borates. Mass transport effects are observed above a current density of approximately $50 \mathrm{~mA} \mathrm{~cm}^{-2}$. The curve corresponding to the power density versus current density shows a maximum point of $34 \mathrm{~mW} \mathrm{~cm}^{-2}$ at a current density of $37 \mathrm{~mA} \mathrm{~cm}^{-2}$. Two-cell and four- cell stacks were tested with the same electrolyte solutions as the unit cell. The stacks were arranged in the bipolar mode. For 2-cell and 4-cell stacks a proportional increase of power density and cell voltage was found. The power density improved considerably when the electrolyte temperature was increased.

A similar sodium borohydride-hydrogen peroxide fuel cell has been reported by researchers using different cells. For example, Raman et al. [73] reported a $28 \mathrm{~W}$ portable direct borohydrideperoxide fuel cell using $4 \%$ wt. aqueous $\mathrm{NaBH}_{4}$ in $20 \mathrm{wt}$.\% aqueous $\mathrm{NaOH}$ coupled with $2 \mathrm{~mol} \mathrm{dm}{ }^{-3} \mathrm{H}_{2} \mathrm{O}_{2}$ in $1.5 \mathrm{~mol} \mathrm{dm}^{-3} \mathrm{H}_{2} \mathrm{SO}_{4}$. The authors used a membrane electrode assembly with a Misch metal anode and gold plate stainless steel cathode divided by a Nafion 916 membrane. The authors reported a peak power density of $50 \mathrm{~mW} \mathrm{~cm}^{-2}$ using a six-cell fuel cell stack which is $30 \%$ higher than the power density obtained with the FM01 $\left(35 \mathrm{~mA} \mathrm{~cm}^{-2}\right)$ cell described above. It should be realised that the concentration of hydrogen peroxide in the work reported by Raman et al. [73] was $2 \mathrm{~mol} \mathrm{dm}^{-3}$ [73] whereas in the work reported by Ponce de Leon at al., it was $1 \mathrm{~mol} \mathrm{dm}^{-3}$ [14].

The uniform hydrodynamic conditions, current distribution and potential distribution together with the facility to implement changes such as temperature, electrode distance, pressure and electrode configurations (either bipolar or monopolar electrodes) or slotted electrodes renders the FM01 a very versatile electrochemical cell. Its use for energy storage investigations is a reliable and convenient way to try different operational conditions and electrode types but once suitable conditions have been identified perhaps other types of cell, which are more lightweight and easier to assemble can be used. (The FM01 cell has two heavy metal endplates to compress the electrodes and spacers in between, which will makes for a low specific energy density).

In a further study by Ponce de Leon et al. [74], different electrocatalysts (Pt on a carbon substrate, and Pd/Ir on a titanium 
surface) were evaluated as cathodes. The power density obtained with a Pd/Ir/Ti electrode was almost 3 times greater that obtained with a Pt-carbon electrode, being similar to that used in the earlier study [14]. This is attributable to the electrochemical reaction mechanisms present in various cathode materials and catalyst loadings. On other hand, electrolyte concentrations and temperature plays and important role on the power density and cell potential. Due to the high reactant concentrations in the electrolytes, a large effect of flow rate on power density and cell potentials was not seen.

The use of undivided cells is attractive to avoid $I R$ drop across the membrane and realise a simpler cell design in redox flow batteries. The soluble lead-acid flow battery is in the early stages of development but has a significant advantage over other systems in its ability to operate with a single electrolyte without the need for a cell-dividing membrane. Wills et al. [15] have described the development and scale-up of the soluble lead redox flow battery using $1.5 \mathrm{~mol} \mathrm{dm} \mathrm{dm}^{-3}$ lead methanesuplhonate in aqueous $1 \mathrm{~mol}$ $\mathrm{dm}^{-3}$ methanesulphonic acid electrolyte containing $1 \mathrm{~g} \mathrm{dm}$ 3 ligninsulphonate crystallization modifier at $25^{\circ} \mathrm{C}$. The desired reversible reactions during discharge are as follows.

At the negative electrode, deposited lead dissolves:

$\mathrm{Pb}-2 \mathrm{e}^{-}=\mathrm{Pb}^{2+} \quad E^{o c}=-0.13 \mathrm{~V}$ vs. SCE

At the positive electrode, the lead dioxide deposit dissolves:

$\mathrm{PbO}_{2}+4 \mathrm{H}^{+}+2 \mathrm{e}^{-}=\mathrm{Pb}^{2+}+2 \mathrm{H}_{2} \mathrm{O} \quad E^{o c}=1.49 \mathrm{Vvs}$. SCE

The overall cell reaction is:

$\mathrm{Pb}+\mathrm{PbO}_{2}+4 \mathrm{H}^{+}=2 \mathrm{H}_{2} \mathrm{O} \quad E_{\text {cell }}^{o c}=1.62 \mathrm{~V}$

An FM01-LC flow reactor was used, firstly in the single cell then in the two-cell, bipolar configuration, before the system was further developed using a custom-built flow cell. The charge/ discharge characteristics for these batteries are discussed along with some of the failure modes encountered during the scale-up process. An FM01-LC laboratory reactor was constructed [15,72], using stainless-steel plates for the current collectors and end plates. The electrode materials were reticulated vitreous carbon (RVC), carbon felt, or nickel foam. The electrodes were aligned therefore that the flow of electrolyte was length wise and the geometric area of each electrode was $4 \mathrm{~cm}$ wide and $16 \mathrm{~cm}$ long. The RVC foam was 1 or $13 \mathrm{~mm}$ thick, the carbon felt was $8 \mathrm{~mm}$ thick and the nickel foam was $1 \mathrm{~mm}$ thick. A number of bipolar electrodes were considered. In all cases, the electrode material was either RVC or Ni foam. The support for the RVC of Ni foams was made from stainless-steel, carbon, or a PTFE gasket. For the PTFE gasket, the carbon cement also formed a barrier between cells preventing leakage currents. An interelectrode gap of $4 \mathrm{~mm}$ was established using elastomeric gaskets, which also formed the flow channel. The cell was operated either as a two electrode, parallel plate reactor or as a four-electrode, two-cell, bipolar stack.

During battery testing, the typical stack voltage for the two cells was $3.7 \mathrm{~V}$ during charge and $3.4 \mathrm{~V}$ during discharge, the individual cell potential being approximately $1.8 \mathrm{~V}$ during charge and $1.7 \mathrm{~V}$ during discharge. Within a multi-cell battery it is important that the performance of each cell be comparable. Any disparity between cells would eventually lead to state-of-charge differences and stack failure.

After further conditioning, the cell was subjected to a series of 1 min charge and $1 \mathrm{~min}$ discharge cycles. The current density was incremented by $20 \mathrm{mAcm}^{-2}$ for each subsequent cycle and the battery voltage was recorded. The voltage obtained at various current densities is determined by a number of factors, including $I R$ drop across the electrolyte channel and the electrodes, the kinetics of the two electrode reactions, and mass transport of the lead (II) to and from the electrode surfaces. The charging voltage increased linearly with applied current density, which suggested that the cell/stack resistance (approximately $0.63 \mathrm{ohm}$ ) was the dominant factor. The electrolyte had a relatively high conductivity. During discharge, it is likely that a combination of the kinetics for lead dioxide reduction and mass transport of reaction products away from the electrode surface had a dominant effect on the cell voltage. Operation of a bipolar soluble lead-acid flow battery on a scale 32 times the geometric area of the $2 \mathrm{~cm}^{2}$ electrodes used in previous studies [72].

The FM01-LC cell is a convenient test bed for the evaluation of electrodes and membranes as well as electrolyte flow rate, current density and other process conditions on the efficiency of energy conversion cells but its typical interelectrode gap of $5.5 \mathrm{~mm}$ should be reduced by redesigned flow sections and thin gaskets to achieve a realistic battery geometry.

\subsection{Treatment of process liquors, wastes and groundwater}

The FM01-LC reactor has been used to treat several specialised effluents. For example, the production of nuclear materials within the energy complexes generates large volumes of high-level waste (HLW) that contains high levels nitrate and nitrite as well as low level of radioactive fission products. Due to their very high concentrations, nitrate and nitrite ions are major contributors to environmental release and personnel exposure risks. To overcome this concern, cathodic reduction of these species to gaseous products has been studied. Genders et al. [75] studied the reduction of nitrates and nitrites from a synthetic waste mixture using the FM01-LC electrolyser. The effects of electrode materials, cell design, and other experimental parameters were investigated. Lead was found to be the best cathode material in terms of current efficiency for the reduction of nitrate and nitrite in the synthetic mix. The current efficiency for nitrite and nitrate removal is improved in divided cells due to the elimination of anodic oxidation of nitrite. Operation of the divided cells at high current densities $\left(300-600 \mathrm{~mA} \mathrm{~cm}^{-2}\right)$ and high temperatures $\left(80^{\circ} \mathrm{C}\right)$ provides more efficient reduction of the ions. Nearly complete reduction of nitrite and nitrate to nitrogen, ammonia, or nitrous oxide was demonstrated in $1000 \mathrm{~h}$ tests in a divided laboratory electrochemical flow cell using a lead cathode, a Nafion 417 cation exchange membrane, and oxygen evolving DSA or platinum clad niobium anode at a current density of $500 \mathrm{mAcm}^{-2}$ and a temperature of $70^{\circ} \mathrm{C}$. Over $99 \%$ of the nitrite and nitrate was removed from the synthetic waste batch in the $1000 \mathrm{~h}$ tests at an overall destruction efficiency of 55\%. The process developed shows promise for treating large volumes of waste.

The treatment of groundwater containing arsenic by electrocoagulation to realise drinking water has been studied in FM01-LC reactor using 3-cell stack with aluminium as the sacrificial anode [76]. Groundwater collected from a $320 \mathrm{~m}$ deep well located in Guanajuato, Mexico, containing $50 \mu \mathrm{g} \mathrm{dm}^{-3}$ arsenic, $40 \mathrm{mg} \mathrm{dm}^{-3}$ carbonates, $80 \mathrm{mg} \mathrm{dm}^{-3}$ hardness, $\mathrm{pH} 7.5$ and $150 \mathrm{mS} \mathrm{cm}^{-1}$ conductivity, was treated. Prior to EC experiments, arsenite ions in the groundwater were oxidized to arsenate ions by addition of $1 \mathrm{mg} \mathrm{dm}^{-3}$ hypochlorite, which is typically used for disinfection. Arsenate removal by electrocoagulation might involve adsorption on aluminium hydroxides generated in the process. Arsenate depletion from 50 to $3.9 \mathrm{mg} \mathrm{dm}^{-3}$ was achieved at a current density of $6 \mathrm{~mA} \mathrm{~cm}^{-2}$ and a mean linear electrolyte flow velocity of $1.8 \mathrm{~cm} \mathrm{~s}^{-1}$, with an energy consumption of $3.9 \mathrm{kWh} \mathrm{m}^{-3}$. The importance of avoiding oxygen evolution during the anodic dissolution of aluminium was noted. 


\section{Summary and outlook}

It is important to use a controlled flow cell in many studies of process development since the electrolyte flow can affect the selectivity of a synthesized product, the lifetime of a reactive intermediate, the rate of mass transport to and from the electrodes and facilitate gas evolution in addition to providing reactants, removing products and assisting control of heat transfer. The reaction environment in the FM01-LC cell has been extensively characterised as will be illustrated in a complementary review. Due to a high and uniform mass transport towards the electrodes, the cell has been used to study many electrode processes such as electrosynthesis, electrochemical degradation of environmental contaminants, metal ion removal and energy storage.

The influence of uniform hydrodynamics, on mass transport and tertiary potential distribution, is an important issue for the success of applications using this filter-press reactor. The ability to install different electrode and channel configurations is one of its principal advantages. From theoretical and experimental studies, it is important that future designs based on the FM01-LC or similar reactors must present modifications of flow and electrode geometry to improve the uniformity of hydrodynamics in the cell. A complementary review will consider computational and experimental characterization of reaction environment in the FM01-LC reactor in more detail.

Uniform hydrodynamics, mass transport and potential distribution together with versatility in the choice of electrodes and membranes make laboratory flow cells, such as the FM01-LC, a recommended technology to evaluate other electrochemical systems such as electrocoagulation, electrodialysis, peroxide production and Li-ion battery technologies, prior to larger scale, industrial processing.

\section{Acknowledgements}

The authors are grateful to the many research postgraduates and research fellows who have pursued computational and experimental studies of the FM01-LC reactor over many years. FCW thanks Dr John Hammond and Mr David Robinson (ex ICI Chemicals \& Polymers) for their collaboration during the early design and mass transfer characterization of the cells. The authors gratefully acknowledge research funding by EPSRC and Dstl in the UK, CONACYT in Mexico and by industries in both countries.

\section{References}

[1] F.C. Walsh, Electrochemical reactors for environmental treatment and clean electrochemistry: electrode/membrane design and reactor characterisation, Pure App. Chem. 73 (2001) 1819.

[2] F.C. Walsh, A First Course in Electrochemical Engineering, The Electrochemical Consultancy, Romsey, 1993.

[3] R.J. Marshall, F.C. Walsh, A review of some recent electrolytic cell designs, Surf. Technol. 24 (1985) 45.

[4] D. Pletcher, F.C. Walsh, Industrial Electrochemistry, 2nd edn., Blackie Academic \& Professional, UK, 1990.

[5] J.H. Hammond, D. Robinson, F.C. Walsh, Mass Transport Studies in Filterpress Monopolar (FM-type) Electrolysers. 1-Pilot Scale Studies in the FM21-SP Reactor, in: G. Kreysa (Ed.), Electrochemical Cell Design and Optimisation Procedures, 123, John Wiley \& Sons, Inc., Frankfurt Germany, 1990, pp. 279 Dechema Monographs.

[6] D.A. Szanto, P. Trinidad, F.C. Walsh, Evaluation of carbon electrodes and electrosynthesis of coumestan and catecholamine derivatives in the FM01-LC electrolyser, J. App. Electrochem. 28 (1998) 251.

[7] F.F. Rivera, C. Ponce de León, F.C. Walsh, J.L. Nava, The reaction environment in the FM01-LC filter-press laboratory electrolyser. A Review, Electrochim. Acta, submitted December 2015.

[8] A. Galia, Electrochemical synthesis of D,L-homocysteine thiolactone hydrochloride in a batch continuous recirculation reactor equipped with carbon felt cathodes: A study for the optimization of the process, Ind. Eng. Chem. Res. 46 (2007) 2360.
[9] T.R. Ralph, M.L. Hitchman, J.P. Millington, F.C. Walsh, Evaluation of a reactor model and cathode materials for batch electrolysis of L-cystine hydrochloride, J. Electroanal. Chem. 462 (1999) 97-110.

[10] V. Reyes-Cruz, I. González, M.T. Oropeza, Electro-recovery of gold and silver from a cyanide leaching solution using a three-dimensional reactor, Electrochim. Acta 49 (2004) 4417.

[11] J.E. Terrazas-Rodriguez, S. Gutierrez-Granados, M.A. Alatorre-Ordaz, C. Ponce de Leon, F.C. Walsh, A comparison of the electrochemical recovery of palladium using a parallel flat plate flow-by reactor and a rotating cylinder electrode reactor, Electrochim. Acta 56 (2011) 9357.

[12] J.L. Nava, F. Núñez, I. González, Electrochemical incineration of p-cresol and o-cresol in the filter-press-type FM01-LC electrochemical cell using BDD electrodes in sulfate media at pH 0, Electrochim. Acta 52 (2007) 3229.

[13] M. Rangel, J.L. Nava, J.M. Peralta-Hernández, G. Carreño, R.J. Guerra-Sánchez, Electrochemical oxidation of Reactive Blue 222 on boron-doped diamond electrodes, Int. J. Electrochem. Sci. 8 (2013) 3310.

[14] C. Ponce de León, F.C. Walsh, A. Rose, J.B. Lakeman, D.J. Browning, R.W. Reeve, A direct borohydride-acid peroxide fuel cell, J Power Sourc. 164 (2007) 441.

[15] R.G.A. Wills, J. Collins, D. Stratton-Campbell, C.T.J. Low, D. Pletcher, F.C. Walsh, Developments in the soluble lead-acid flow battery, J. Appl. Electrochem. 40 (2010) 955.

[16] R.L. Clarke, B.J. Dougherty, S. Harrison, J.P. Millington, Battery with bifunctional electrolyte, U.S. Pat. Appl. Publ. WO 2004/095602 A2 (2004).

[17] J.E. Harrar, R.K. Pearson, Electrosynthesis of $\mathrm{N}_{2} \mathrm{O}_{5}$ by controlled-potential oxidation of $\mathrm{N}_{2} \mathrm{O}_{4}$ in Anhydrous $\mathrm{HNO}_{3}$, J. Electrochem. Soc. 130 (1983) 108.

[18] D.J. Schiffrin, S.A. Campbell, G.E.G. Bagg, R.J. Marshall, F.C. Walsh, Electrosynthesis of dinitrogen pentoxide in anhydrous nitric acid using a laboratory filter-press flow reactor, Electrochim. Acta (2014), to be submitted.

[19] J.E. Harrar, R. Quong, L.P. Rigdon, R.R. McGuire, Scale-up studies of the electrosynthesis of dinitrogen pentoxide in nitric acid, J. Electrochem. Soc. 144 (1997) 2032.

[20] G.E.G. Bagg, R.J. Marshall, D.J. Schiffrin, F.C. Walsh, UK Patent Applications 8714156 and 8714157, (1987).

[21] J.E. Harrar, R. Quong, L.P. Rigdon, R.R. McGuire, Large-scale production of anhydrous nitric acid and nitric acid solutions of dinitrogen pentoxide, US Patent Application 6200456 B1, (1987).

[22] F.C. Walsh, C. Ponce de Leon, The deposition of nanostructured surfaces by electrochemical techniques: a range of emerging surface finishes, Trans. Inst. Mats. Finish. 92 (2014) 83.

[23] J. Recio, P. Herrasti, L. Vasquez, C. Ponce de Leon, F.C. Walsh, Mass transfer to a nanostructured nickel electrodeposit of high surface area in a rectangular flow channel, Electrochim. Acta 90 (2013) 507.

[24] T.R. Ralph, M.L. Hitchman, J.P. Millington, F.C. Walsh, Mass transport in an electrochemical laboratory filter-press reactor and its enhancement by turbulence promoters, Electrochim. Acta 41 (1996) 591.

[25] D. Pletcher, F.C. Walsh, Three-dimensional electrodes, in: J.D. Genders, N.L. Weinberg (Eds.), Electrochemical Technology for a Cleaner Environment, The Electrosynthesis Company Inc., Lancaster, New York, 1992.

[26] F.C. Walsh, G.W. Reade, The design and performance of electrochemical reactors for efficient synthesis and environmental treatment, Analyst. 119 (1994) 791.

[27] F.C. Walsh, G.W. Reade, Electrochemical techniques for the treatment of dilute metal ion solutions, in: C.A.C. Sequeira (Ed.), Environmentally Oriented Electrochemistry, Elsevier, Amsterdam, 1994, pp. 3.

[28] S.W. Price, S.J. Thompson, X. Li, S.F. Gorman, D. Pletcher, A.E. Russell, F.C. Walsh, R.G.A. Wills, The fabrication of a bifunctional oxygen electrode without carbon components for alkaline secondary batteries, J. Power Sourc. 259 (2014) 43.

[29] X. Li, F.C. Walsh, D. Pletcher, Nickel-based electrocatalysts for oxygen evolution in high current density alkaline water electrolysers, Phys Chem Chem Phys 13 (2010) 1162.

[30] A. Kulak, S. Williams, I. Merino-Jiménez, C. Ponce de León, F.C. Walsh, Improvements in the direct borohydride fuel cell using three-dimensional electrodes, Catal. Today 70 (2011) 149.

[31] T.M. Tseng, R.-H. Huang, C.-Y. Huang, K.-L. Hsueh, F.-S. Shieu, A kinetic study of the platinum/carbon anode catalyst for vanadium redox flow battery, J. Electrochem. Soc. 160 (2013) A690.

[32] C. Bengoa, A. Montillet, P. Legentilhomme, J. Legrand, Characterization and modeling of the hydrodynamic behavior in the filter-press-type FM01-LC electrochemical cell by direct flow visualization and residence time distribution, Ind. Eng. Chem. Res. 29 (2000) 2199.

[33] L. Castañeda, R. Antaño, F.F. Rivera, J.L. Nava, Residence time distribution and flow visualization in a filter-press electrolyzer using computational fluid dynamics: effect of net plastic used as turbulence promoter. Compu Chem Eng. (2014), to be submitted.

[34] C.J. Brown, D. Pletcher, F.C. Walsh, J.K. Hammond, D. Robinson, Local mass transport effects in the FM01 laboratory electrolyser, J. Appl. Electrochem. 22 (1992) 613.

[35] D.A. Szánto, S. Cleghorn, C. Ponce de León, F.C. Walsh, The limiting current for reduction of ferricyanide ion at nickel: the importance of experimental conditions, A.I.Ch.E. Journal 54 (2008) 802-810.

[36] C.J. Brown, D. Pletcher, F.C. Walsh, J.K. Hammond, D. Robinson, Studies of three-dimensional electrodes in the FMO1-LC laboratory electrolyser, J. Appl. Electrochem. 24 (1994) 95-106.

[37] Ineos Chlor-Chem, http://www.ineos.com/businesses/ineos-technologies/ technologies/Access 15 December 2014. 
[38] C.J. Brown, D. Pletcher, F.C. Walsh, J.K. Hammond, D. Robinson, Studies of space-averaged mass transport in the FM01-LC laboratory electrolyser, J. Appl. Electrochem. 23 (1993) 38.

[39] M. Griffiths, C. Ponce de León, F.C. Walsh, Mass transport in the rectangula channel of a filter-press electrolyzer (the FM01-LC reactor), A.I.Ch.E. Journal 51 (2005) 682.

[40] C.J. Brown, F.C. Walsh, D. Pletcher, Mass transport and pressure drop in a laboratory filter-press electrolyser, Trans. I., Chem. Eng. 73A (1994) 196.

[41] L. Vázquez, A. Alvarez-Gallegos, F.Z. Sierra, C. Ponce de León, F.C. Walsh, Simulation of velocity profiles in a laboratory electrolyser using computational fluid dynamics, Electrochim. Acta 55 (2010) 3437.

[42] R. Enciso-Pérez, G. Velasco-Martínez, J.A. Delgadillo, I. Rodríguez-Torres, Computational fluid dynamics of an electrolytic cell FM01-LC, ECS Trans. 20 (2009) 103

[43] E.P. Rivero, F.F. Rivera, M.R. Cruz-Díaz, E. Mayen, I. González, Numerical simulation of mass transport in a filter press type electrochemical reactor FM01-LC: Comparison of predicted and experimental mass transfer coefficient, Chem. Eng. Res. Des. 90 (2012) 1969.

[44] L. Vázquez, A. Alvarez-Gallegos, F.Z. Sierra, C. Ponce de León, F.C. Walsh, Prediction of mass transport profiles in a laboratory filter-press electrolyser by computational fluid dynamics modelling, Electrochim. Acta 55 (2010) 3446.

[45] T. Pérez, M.I. León, J.L. Nava, Numerical simulation of current distribution along the boron-doped diamond anode of a filter-press-type FM01-LC reactor during the oxidation of water, J. Electroanal. Chem. 707 (2013) 1.

[46] D.A. Szánto, P., Trinidad, I., Whyte, F.C. Walsh Electrosynthesis and mass transport measurements in a laboratory filter-press electrolyser, 4th European Symposium on Electrochemical Engineering, Prague, Czech Republic, 25-30 August 1996, 273.

[47] P. Trinidad, F.C. Walsh, C. Ponce de León, The application of flow dispersion models to the FM01-LC laboratory filter-press reactor, Electrochim. Acta 52 (2006) 604

[48] F.F. Rivera, M.R. Cruz-Díaz, E.P. Rivero, I. González, Analysis and interpretation of residence time distribution experimental curves in FM01-LC reactor using axial dispersion and plug dispersion exchange models with closed-closed boundary conditions, Electrochim. Acta 56 (2010) 361.

[49] M. Cruz-Díaz, F.F. Rivera, E.P. Rivero, I. González, The FM01-LC reactor modelling: using axial dispersion model with a reaction term coupled with a continuous stirred tank, Electrochim. Acta 63 (2012) 47.

[50] M. Chikhi, M. Rakib, S. Ph Viers, Laborie, A. Hitab, G. Durand, Curren distribution in a chlor-alkali membrane cell: experimental study and modelling, Desalination 149 (2002) 375.

[51] J.E. Funk, J.F. Thorpe, Void fraction and current density distributions in a wate electrolysis cell, J. Electrochem. Soc. 116 (1969) 48.

[52] F.C. Walsh, D. Robinson, Electrochemical synthesis and processing in modern filter-press reactors, Chemical Technology Europe, 1995, pp. 16 May/June.

[53] C.Z. Smith-James, H.P. Utley, J.K. Hammond, Electro-organic reactions. Part 60 The electro-oxidative conversion at laboratory scale of a lignosulfonate into vanillin in an FM01 filter press flow reactor: preparative and mechanistic aspects, J. Appl. Electrochem. 41 (2011) 363.

[54] G.A. Olah, R. Malhotra, S.C. Narang, Nitration: Methods and Mechanisms, Reagents and methods of aromatic nitration, VCH, New York, 1989, pp. 55 Chapter 2.

[55] ICI Publication, Electrotech. Review, Issue 5, 1991.

[56] C. Ponce de Leon, R.W. Field, Comparison of anionic membranes used to concentrate nitric acid to beyond the azeotropic mixture, J. Membrane Sci. 171 (2000) 67.

[57] G.T. Lapidus-Lavine, I. González, J.L., Nava, R., Benavides, C. Lara-Valenzuela, in: C.A. Young, P.R., Taylor, C.G., Anderson, Y. Choi (Ed.) Mineral and Metal Processing VI, 2006, 777.
[58] F.C. Walsh, The role of the RCE reactor in metal ion removal, in: J.D. Genders, N. L. Weinberg (Eds.), Electrochemistry for a Cleaner Environment, The Electrosynthesis Company Inc., Lancaster, New York, 1992, pp. 101.

[59] O. González-Pérez, S. Castro-Larragoitia, I. Rodríguez-Torres, Preliminary studies on the electrochemical recovery of $\mathrm{Zn}$ and $\mathrm{Cd}$ from effluent produced by a zinc refinery plant using a filterpress reactor, J Chem Technol. Biotechnol 88 (2013) 1371.

[60] Reducing Costs in Hard Chrome Plating ETSU Leaflet FP91, 1999; ETSU, Harwell, Didcot, Oxon OX11 ORA, UK; a collaborative project with Poeton Industries Ltd. PMD (UK) Ltd. Elementis Chromium and FHM Division, Claverham Ltd.

[61] P.M. Bersier, C.P. de León, F.C. Walsh, Electrochemical approaches to environmental treatment and recycling, in: J. Feliu, V. Martinez, V. Climent (Eds.), Encyclopedia of Life Support Systems (EOLSS), EOLSS Publishers, Oxford, UK, 2008.

[62] R. Rousell, Cerium mediated electrosynthesis, Master of applied sciences thesis, University of British Columbia, Canada, 1996.

[63] J.L. Nava, A. Recéndiz, J.C. Acosta, I. González, Electrochemical incineration of vinasse in filter-press-type FM01-LC reactor using 3D BDD electrode, Wat. Sci. Tech. 58 (2008) 2412.

[64] G. Coria, J.L. Nava, G. Carreño, Electrooxidation of diclofenac in synthetic pharmaceutical wastewater using an electrochemical reactor equipped with a boron doped diamond electrode, Mex. J. Chem. Soc. 58 (2014) 303.

[65] E. Butrón, M. Juárez, M. Solís, M. Teutli, I. González, J.L. Nava, Electrochemical incineration of indigo textile dye in filter-press-type FM01-LC electrochemical cell using BDD electrodes, Electrochim. Acta 52 (2007) 6888.

[66] J.L. Nava, E. Butrón, I. González, Importance of hydrodynamic conditions on the electrochemical incineration of cresols, indigo textile and vinasses present in industrial wastewater using a filterpress type FM01-LC reactor with BDD electrodes, J. Environ. Eng. Management 18 (2008) 221.

[67] C.A. Martínez-Huitle, E. Brillas, Decontamination of wastewaters containing synthetic organic dyes by electrochemical methods: A general review, App. Cat. B 87 (2009) 105.

[68] O. López, I. González, J.L. Nava, Electrochemical incineration of indigo textile dye in filter-press type FM01-LC electrochemical cell using mesh-DSA anode, ECS Trans. 15 (2008) 395.

[69] J.L. Nava, I. Sirés, E. Brillas, Electrochemical incineration of indigo. A comparative study between 2D (plate) and 3D (mesh) BDD anodes fitted into a filter-press reactor, Environ. Sci. Pollut. Res. (2014) submitted.

[70] C.A. Martínez-Huitle, E. Vieira dos Santos, D. Medeiros de Araújo, M. Panizza, Applicability of diamond electrode/anode to the electrochemical treatment of a real textile effluent, J. Electroanal. Chem. 674 (2012) 103.

[71] A. Frias-Ferrer, J. Gonzalez-Garcia, D.A. Szánto, C. Ponce-de-León, F.C. Walsh, Redox flow cells for energy conversion, J. Power Sourc. 160 (2006) 716.

[72] C.P. Zhang, S.M. Sharkh, X. Li, F.C. Walsh, C.N. Zhang, J.C. Jiang, The performance of a soluble lead acid flow battery and the comparative performance of a static lead-acid battery, Energy Conversion and Management 52 (2011) 3391.

[73] R.K. Raman, S.K. Prashant, A.K. Shukla, A 28-W portable direct borohydridehydrogen peroxide fuel-cell stack, J. Power Sources 162 (2006) 1073-1076.

[74] C. Ponce de León, F.C. Walsh, C.J. Patrissi, M.G. Medeiros, R.R. Bessette, R.W. Reeve, J.B. Lakeman, A. Rose, D. Browning, A direct borohydride-peroxide fuel cell using a Pd/Ir alloy coated microfibrous carbon cathode, Electrochem. Comm. 10 (2008) 1610.

[75] J.D. Genders, D. Hartsough, D.T. Hobbs, Electrochemical reduction of nitrates and nitrites in alkaline nuclear waste solutions, J. Appl. Electrochem. 26 (1996) 1.

[76] J.L. Flores, Arsenic removal from groundwater by electrocoagulation process in a filter-press-type FM01-LC reactor, Int. J. Electrochem. Sci. 9 (2014) 6658. 